IZA DP No. 4176

Still Waiting for Mister Right?

Asymmetric Information, Abortion Laws and the Timing of Marriage

Simon W. Bowmaker

Patrick M. Emerson

May 2009 


\title{
Still Waiting for Mister Right? Asymmetric Information, Abortion Laws and the Timing of Marriage
}

\author{
Simon W. Bowmaker \\ New York University \\ Patrick M. Emerson \\ Oregon State University \\ and IZA
}

Discussion Paper No. 4176

May 2009

IZA

P.O. Box 7240

53072 Bonn

Germany

Phone: +49-228-3894-0

Fax: +49-228-3894-180

E-mail: iza@iza.org

\begin{abstract}
Any opinions expressed here are those of the author(s) and not those of IZA. Research published in this series may include views on policy, but the institute itself takes no institutional policy positions.

The Institute for the Study of Labor (IZA) in Bonn is a local and virtual international research center and a place of communication between science, politics and business. IZA is an independent nonprofit organization supported by Deutsche Post Foundation. The center is associated with the University of Bonn and offers a stimulating research environment through its international network, workshops and conferences, data service, project support, research visits and doctoral program. IZA engages in (i) original and internationally competitive research in all fields of labor economics, (ii) development of policy concepts, and (iii) dissemination of research results and concepts to the interested public.
\end{abstract}

IZA Discussion Papers often represent preliminary work and are circulated to encourage discussion. Citation of such a paper should account for its provisional character. A revised version may be available directly from the author. 


\section{ABSTRACT}

\section{Still Waiting for Mister Right? Asymmetric Information, Abortion Laws and the Timing of Marriage*}

Previous studies have suggested that more liberal abortion laws should lead to a decrease in marriage rates among young women as 'shotgun weddings' are no longer necessary. Empirical evidence from the United States lends support to that hypothesis. This paper presents an alternative theory of abortion access and marriage based on asymmetric information, which suggests that more liberal abortion laws may actually promote young marriage. An empirical examination of marriage data from Eastern Europe shows that countries that liberalized their abortion laws saw an increase in marriage rates among nonteenage women.

JEL Classification: J12, J13, K0

Keywords: abortion, marriage asymmetric information

Corresponding author:

Patrick M. Emerson

Department of Economics

Oregon State University

303 Ballard Hall

Corvallis, Oregon 97331

USA

E-mail: patrick.emerson@oregonstate.edu

\footnotetext{
*For useful comments and advice, we thank Doug Staiger, Ian Smith, Laura Argys, Michael Katz, Naci Mocan and seminar participants at the University of Oregon, the University of St Andrews and Reed College.
} 
"For us women, it's really a limited window. We know that boys who grow up to become men don't necessarily want to be men. They like to be boys. And so women say, 'You know what? He's gonna just have to snap out of it - and my pregnancy will be the thing to do it.'

Vicki Iovine, author of The Girlfriends' Guide to Pregnancy.

Economists have long understood how changes in social policy can alter the incentives of individual and group actions leading to behavioural responses. One such social policy is the restrictions a society places on a person's ability to terminate a pregnancy. Changes in such restrictions can alter both male and female incentives to engage in premarital sex, to seek premarital commitments and to enter marriage itself.

Previous theoretical work has generally assumed that liberalizing abortion laws would lead to a decrease in marriage rates among young women from the subsequent decline in 'shotgun weddings.' This paper presents a competing theory that focuses on the nature of the asymmetric information problem in the mating game. If pregnancy is an effective information revelation mechanism, liberalization of abortion laws can reduce the cost of, and speed up the process of, learning and lead to increased marriage rates among young women. We test the implications of this theory empirically by examining a period of rapid change in abortion restrictions in Eastern Europe and the effect these changes had on the marriage rates of women. We find that, contrary to the predictions of the perceived theory, more liberal abortion laws have been associated with increases in female marriage rates for non-teenage women.

Several previous economic studies investigate the relationship between abortion access and marriage in the United States. In Akerlof, et al. (1996), for instance, increased availability of abortion is theorized to lead to a decline in marriage rates among females for two reasons. First, 
since abortion now acts as a form of 'insurance policy', women no longer need to insist upon a marriage promise, in the event of pregnancy, as a precondition for premarital sex. Second, with increased access to abortion, males may feel less responsibility to marry their partners in the event of an unplanned pregnancy since fertility is now a decision on their part. For both reasons, increased access to abortion should lead to lower incidence of 'shotgun weddings,' or weddings that occur due to an unplanned pregnancy. ${ }^{1}$ This theory states then that a decrease in forced marriages due to unplanned pregnancies should lead to more delays in first marriage as abortion laws are liberalized, and lower first marriage rates among women across the entire fertility age range (15 to 44 years-old).

The present study proposes a competing theory of abortion access and marriage which extends the work of Kane and Staiger (1996), who argue that pregnancy reveals information about the attractiveness of parenthood and abortion provides insurance in case that information is negative. It is suggested that a woman considering the suitability of a potential mate for marriage can learn through two channels; slowly gathering information through time, or becoming pregnant and therefore learning quickly, provided she can terminate the pregnancy if the information is negative. A switch to a liberal abortion regime might make the pregnancy route less costly, speed up the learning process on average and, in contrast to the Akerlof et al. (1996) theory, raise first marriage rates among women. Thus the precise effect of abortion laws on marriage outcomes is an empirical question.

\footnotetext{
${ }^{1}$ Chiappori and Oreffice (2008) argue that for Akerlof et al.'s theory to hold, it must be the case that a significant proportion of the male population in the U.S. chose to remain single over this time period, but would have decided (or been forced) to marry had legal abortion not been available. To examine empirically whether legalization of abortion significantly increased the probability of singlehood in the male population, they use data on males aged 15 to 50 from the Current Population Survey March Supplements 1968-1980 and regress a male singlehood dummy on age, education, race and fixed effects by year and state, as well as an abortion legalization dummy for the different states. They find that the abortion dummy is not statistically significant and the coefficient has a negative sign.
} 
There are a few additional previous empirical studies that address similar questions as the present study. Goldin and Katz (2002) argue that access to the birth control pill in the U.S. in the late 1960s and early 1970s lowered the marriage market cost to young women who delayed marriage in order to pursue a career and they find some evidence that birth control as well as abortion access resulted in delayed marriage for young women. Two other studies exploit the cross-state variation in abortion access in U.S. states in the early 1970s to examine the effects on marriage rates. Evans and Angrist (1999) find a negative effect of abortion liberalization on the probability that a white woman married by the age of twenty. Choo and Siow (2006) find a negative effect of partial legalization of abortion on marriage rates for both young men and women. Rasul (2003) and Alesina and Giuliano (2007) examine the impact of adoption of unilateral divorce laws in the U.S. on marriage rates, but also control for the liberalization of abortion laws. Rasul (2003) reports a statistically significant negative relationship between abortion legalization and marriage rates. Alesina and Guiliano (2007) also report a negative relationship, although their finding is not statistically significant.

The paper proceeds as follows. Section 1 provides a more detailed comparison of the theories exploring the relationship between abortion access and marriage. Section 2 contains a descriptive overview of the data used in the paper's empirical analysis. Section 3 presents the study’s methodology and results. Section 4 outlines the conclusions of the paper.

\section{Abortion laws and entry into marriage: the theoretical framework}

To understand how abortion access affects entry into marriage, the decision to engage in sexual intercourse by unmarried women is first examined. In a traditional economic framework, an unmarried woman is assumed to evaluate the costs and benefits of sexual activities before 
engaging in sexual intercourse with a man (Posner, 1992; Levine, 2000; Klick and Stratman, 2006). One of the most obvious drawbacks is the possibility of an unplanned pregnancy occurring, which is associated with considerable costs. On the one hand, there are several direct costs, including the monetary costs attached to giving birth to and raising a child. On the other hand, there are also indirect costs to consider. For example, an unplanned pregnancy may result in a woman having to forego opportunities in education and in the labour market (Angrist and Evans, 1996) and may also generate social or familial opprobrium. This raises the possibility that a woman (and her partner) may be 'forced' into a shotgun wedding (that is, marriage that takes place after pregnancy occurs, but before the birth of the child). Access to abortion can eliminate these costs by eliminating their source (although replacing them with the actual financial and emotional cost of the abortion itself).

To fix ideas, consider a simple game. The player of this game is a single woman who wishes to find a man to marry and have a child with. She obtains some value from the process of dating and we denote this value as $\mathrm{V}$. In the first move she receives a random draw of a man who can be either a 'Dad,' also interested in marriage and parenthood, or a 'Cad,' someone who only wants to date and does not want marriage or a child. The proportion of Dads in the population is denoted $\phi$, and thus the proportion of Cads is $1-\phi$. Once the draw is made the woman does not know what type of man she has ended up with and therefore the decision node has a single information set.

There are two ways the woman can find out the man's type: she can wait and through the process of dating learn his type, or she can get pregnant and learn his type immediately through his reaction to the pregnancy. Once she waits and learns the true type she can dump the man or get pregnant in which case she will either be a single mom (if his type is Cad) or a married 
mother (if his type is Dad). If she uses pregnancy to reveal the information she can remain pregnant or abort.

We denote the full cost of an abortion (inclusive of all cost) as C. The value of single motherhood is $S$ and the value of married motherhood is $M$. We assume that $C>0, S<M$, and $\mathrm{S}<\mathrm{V}<\mathrm{M}$. The woman also has a discount factor for waiting a period, which is denoted $\delta$. Thus, if she aborts, she re-enters the game the next period, so her payoff is $\delta \mathrm{V}$. This discount factor could also be an increasing function of age during the period of fertility, but for present purposes we shall model it as independent of age. We illustrate the game with the following game tree.

Figure 1 The Dads and Cads Game

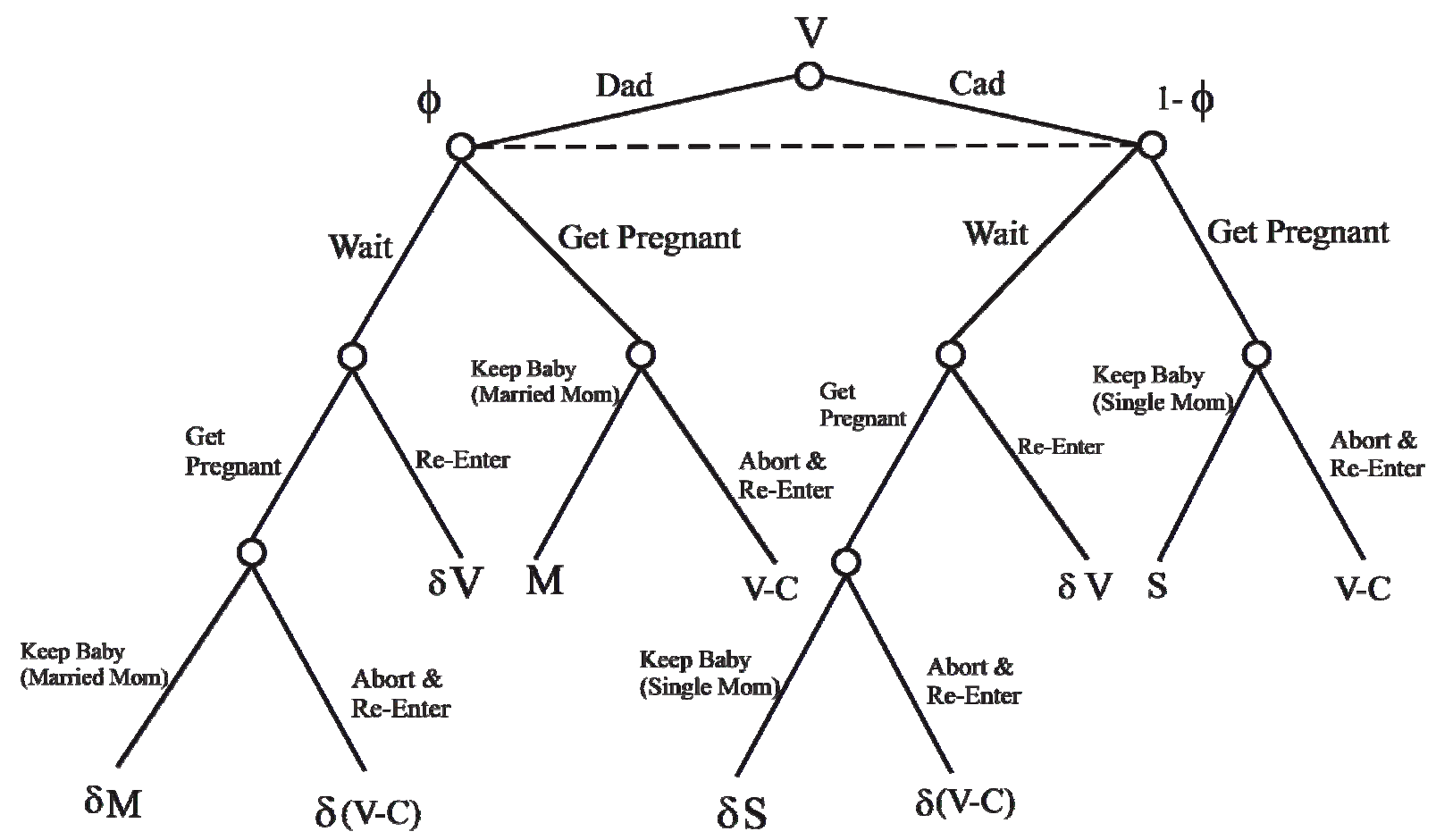


Abortion laws affect the cost of abortion, C. We have to examine two cases. This first case is when the cost of abortion is low enough such that $\mathrm{V}-\mathrm{C} \geq \mathrm{S}$, or once a woman receives a draw of a man, she can get pregnant to reveal type and will chose to abort in the case of a Cad. We call that the weak abortion law case. The second case is when the cost of abortion is so high such that V$\mathrm{C}<\mathrm{S}$, which means that the woman will choose to keep the baby even if the man is revealed to be a Cad. We call that the strict abortion law case. In either case, we assume that $\mathrm{V}-\mathrm{C}<\mathrm{M}$, meaning that a woman will always choose to keep a baby if the man is revealed to be a Dad.

Note that by assumption a (risk-neutral) woman who chooses to wait will receive an expected present value payoff of: $\delta \phi \mathrm{M}+(1-\phi) \delta \mathrm{V}$. Since $\mathrm{V}$ is defined as the value at the start of the game, we can solve this recursive problem for the value of $\mathrm{V}$ if the woman waits:

$$
\mathrm{V}_{\mathrm{w}}=\frac{\delta \phi \mathrm{M}}{1-\delta+\delta \phi}
$$

We can now calculate the payoff a woman receives from getting pregnant in both a weak abortion law regime and a strict abortion law regime. If a woman gets pregnant under a strict abortion law regime then the expected present value of this strategy is:

$$
\mathrm{V}_{\mathrm{P}}=\phi \mathrm{M}+(1-\phi) \mathrm{S}
$$

If a woman gets pregnant under a weak abortion law regime the expected present value of this strategy is:

$$
\mathrm{V}_{\mathrm{P}}=\mathrm{M}-\frac{1-\phi}{\phi} \mathrm{C}
$$


A woman will therefore choose to become pregnant and force information revelation if and only if:

$$
\mathrm{V}_{\mathrm{P}} \geq \mathrm{V}_{\mathrm{W}}
$$

or,

$$
\begin{aligned}
& \phi \mathrm{M}+(1-\phi) \mathrm{S} \geq \frac{\delta \phi \mathrm{M}}{1-\delta+\delta \phi} \text { in the strict case, and } \\
& \mathrm{M}-\frac{1-\phi}{\phi} \mathrm{C} \geq \frac{\delta \phi \mathrm{M}}{1-\delta+\delta \phi} \text { in the weak case. }
\end{aligned}
$$

In the strict case either strategy is possible, so once $\mathrm{C}$ is high enough such that $\mathrm{V}-\mathrm{C}<\mathrm{S}$, any additional cost of abortion no longer has any effect on a woman's decision to wait or get pregnant. It is therefore the weak case that is of interest to this analysis. It is immediately clear that in the weak case, the higher is $\mathrm{C}$, or the less liberal are abortion laws, the less likely is a woman to employ the strategy of getting pregnant and the more likely she is to wait. Conversely, the more liberal are abortion laws, the more likely is a woman to get pregnant to find out a man's type. The decision-tree in Figure 1 provides a summary of this game.

As an extension, we can consider the discount factor $\delta$ as a function of the age of the woman, $\delta$ (age), where $\delta^{\prime}$ (age) $<0$. This reflects the fact that a woman's fertile years are limited and the cost of repeating the game increases through time. Since $\frac{\mathrm{dV}_{\mathrm{W}}}{\mathrm{d}(\text { age })}=\frac{\mathrm{dV}_{\mathrm{w}}}{\mathrm{d} \delta} * \delta^{\prime}$ (age)

and $\frac{\mathrm{dV}_{\mathrm{w}}}{\mathrm{d} \delta}>0$, it must be the case that $\frac{\mathrm{dV}_{\mathrm{W}}}{\mathrm{d}(\text { age })}<0$, or that the woman is more likely to pursue the pregnancy strategy as she gets older.

In summary, a switch to a more liberal abortion law in the model can influence marriage rates because pregnancies will be affected. Specifically, every non-marital pregnancy will be 
associated with a probability that the man will turn out to be a 'Dad' and therefore marry the woman before the child is born. Since more pregnancies are likely to take place, some of these will lead to marriage. Furthermore, the response time of women to the policy shift is likely to be fairly rapid in this game since their behaviour reflects changes in the woman's own actions with little or no regard to the broader social environment. By contrast, in the Akerlof et al. (1996) game, social norms are required to change in response to the switch in abortion policy, since we observe effects on competition among women and bargaining power between men and women.

The presence of competing theories of access to abortion and marriage suggests that the net effect of a more liberal abortion law on entry into marriage is an empirical issue. The next section presents an empirical investigation of abortion law liberalization in Eastern Europe and its effect on marriage rates among young women.

\section{Data description and methodology}

The economic and political transition in Eastern Europe of the late 1980s and early 1990s was associated with a drastic transformation in family life. The data show considerable changes in trends affecting families, such as an abrupt fall in total fertility rates but a corresponding steep rise in the proportion of extra-marital births. Single-parent families increased relative to all families and the average size of families and households dropped significantly. Further, there were major changes in patterns of union formation, as marriage rates declined to very low levels and individuals postponed marriage to a later age. These trends took place against the backdrop of radical changes in social policy in Eastern Europe. For example, over the transitional period of the late 1980s and early 1990s, several countries made amendments to laws relating to access to abortion. For most countries in the region, this took the form of eliminating varying degrees of 
restrictions that existed under the former communist regime, although one country (Poland) tightened abortion laws even further. Those countries, mainly from the former Soviet Republic, which already had in place fairly liberal abortion laws prior to the transitional period, did not significantly change their policies relating to abortion.

The analysis that follows uses data from twelve Eastern European countries over the 1980 to 1997 period to estimate the empirical relationship between changes in different types of abortion policies and female entry into marriage. ${ }^{2}$ Eastern Europe is a very useful area to study in this respect since, as mentioned above, both regions experienced both sweeping and diverse changes in abortion laws over those two decades. Further, the issue of whether these changes affected the propensity to marry has not been addressed in the literature. ${ }^{3}$

To examine the impact of changes in abortion policy on entry into marriage, regression models were estimated with each outcome considered as a function of the legal status of abortion, macroeconomic conditions (GDP and inflation), economic and social development (female university enrolment and urbanization) and marriage market conditions (female to male population ratios and divorce laws). The outcomes considered are the female first marriage rates per 1000 females for the following age groups: 15-19, 20-24, 25-29, 30-34, 35-39, and 40-44. The data for the dependent variables are taken from various issues of the Council of Europe’s Demographic Yearbook.

\footnotetext{
${ }^{2}$ The twelve countries are Bulgaria, Czech Republic, Estonia, German Democratic Republic (GDR), Hungary, Latvia, Lithuania, Moldova, Poland, Romania, Russia and Slovak Republic.

3 The data on abortion laws were provided by Doug Staiger and Phillip Levine who have examined the effect of these laws on a range of fertility outcomes in Eastern Europe: Levine, P. and D. Staiger (2004), 'Abortion Policy and Fertility Outcomes: The Eastern European Experience’, Journal of Law and Economics, 47, 1, 223-243.
} 


\subsection{Descriptive analysis of outcome measures}

Over the time period under examination in this paper, traditional patterns of early and universal entry into marriage for females were broken in Eastern Europe, a process that continues today. Table 1 presents mean values of this study's outcome measures in Eastern Europe weighted by the relevant population measure in each country in 1980 and 1995. For comparative purposes, statistics are also reported for Western Europe. The raw data show patterns that are broadly similar in both regions for young women but different for older women. In 1980, the female marriage rates were generally higher than those of 1995 for young women in both Eastern and Western Europe although the magnitude of the decline was considerably greater in Western Europe. For older women the patterns diverge. The marriage rates for older women in Eastern Europe declined while those in Western Europe increased.

Figures 2 and 3 show first marriage rates for 25-29 year olds for the former soviet republics and for the rest of the Eastern European countries respectively. These figures illustrate the changes in marriage rates experienced by those aged 25 to 29 in those countries that did not change their abortion laws during the entire period under study (the former soviet republics) and those countries that liberalised their abortion laws (Bulgaria, Czech Republic, Slovak Republic, Hungary and Romania). Figure 2 shows the downward trend in female first marriage rates in the soviet republics over the 1980 to 1997 period, while Figure 3 shows that female first marriage rates increased significantly in the early 1990s. This behavioural shift closely coincides with the political and economic turmoil brought about by the decline and eventual collapse of the Soviet Union, but it also took place around the time of abortion law changes in these countries. 


\subsection{Description of Abortion Laws}

Abortion laws in the countries of Eastern Europe are currently among the most liberal in the world. In the 1950s, the republics of the former Soviet Union made abortion available on request during the first 12 weeks of pregnancy. In the more recent past, several other Eastern European countries, with the exception of Poland, continued to liberalise their abortion laws, although several restrictive aspects of these laws remain in place. Table A1 of the Appendix presents an overview of these laws in Eastern Europe and highlights the changes that have been implemented since 1980.

The legal status of abortion in each country at a given point in time is placed into one of three categories: ${ }^{4}$

(1) "life/medical" - abortion is only granted in order to save the life of the woman or if she suffers from 'specific, narrow medical' conditions;

(2) "medical/social" - abortion is available if the woman suffers from a broader range of medical problems, including mental health issues, or if it is deemed that hardship would follow from the birth of the child; and

(3) “on request" - abortion is available to a women if she asks for one.

Over the eighteen-year period examined in this paper, there have been a number of changes made to the fundamental legal status of abortion in the Eastern European countries featured in Table A1, particularly by those who were not part of the former Soviet Union. Some of these changes coincided with the movement from communism and democracy in the regions and the abandonment of pro-natalist policies. For example, following the overthrow of dictator Nicolae Ceausescu in late 1989, Romania repealed the 1966 and 1986 decrees restricting access to abortion. Similarly, in early 1990, Bulgaria made abortion available on request to all women

\footnotetext{
${ }^{4}$ This categorization is taken from Levine and Staiger (2004).
} 
in the first 12 weeks of pregnancy, thereby overturning laws passed in 1968 and 1973 which restricted eligibility for abortion to unmarried women and married women with children.

However, there are countries in Eastern Europe which liberalised abortion laws prior to the transitional period of the 1990s. For example, in 1987, six years prior to its split into two republics, Czechoslovakia made abortion available upon request, ending a 30 year-old law which permitted abortion only on medical or social grounds. Not long after the country divided into the Czech and Slovak republics, considerable fees for abortions were introduced. Similar changes were made to Hungarian abortion law in 1993.

The former GDR has been subject to changes in abortion law since German unification. In 1995, several new procedural requirements were introduced, including a three-day waiting period and mandatory counselling to dissuade the woman from having an abortion. Further, most abortions in the ex-GDR are no longer covered by national health insurance (Rahman et al., 1998).

Poland represents the only country in our sample to have significantly tightened access to abortion in the transitional period of the 1990s. Restrictions on funding of abortion began in the spring of 1990, and by 1993, the Polish government, backed by the Catholic Church, had succeeded in overturning the country’s liberal abortion law which had been in place since 1956. The new law limited abortion to cases of threat to the mother's life or health, cases of rape and incest, and serious and irreversible damage to the foetus.

As noted at the beginning of this section, access to abortion in the republics of the former Soviet Union has been available on request both before and after the transition from communism to democracy. The first major change occurred two years after the death of Joseph Stalin in 1953, when abortion prohibition that had been in force since 1936 was abandoned. In 1988, abortion 
laws were further liberalised, with an extension of the termination period and consideration of a broader range of non-medical issues in the decision.

\subsection{Description of control variables}

\subsubsection{Macroeconomic conditions}

Macroeconomic conditions in Eastern Europe are important controls to include in the analysis. First, they are likely to be correlated with political developments that led to changes in abortion laws in Eastern Europe over the 1980 to 1997 period. Second, there are several mechanisms through which an economic crisis (as experienced by almost all the Eastern European countries included in the study period) could either hasten or postpone marriage. To begin with, it has the potential to increase the gains from marriage. For example, the uncertainty associated with an economic crisis enhances the attractiveness of the resource pooling and insurance functions of marriage. In other words, married individuals can reap the benefits of economies of scale, and relationships formed through marriage can extend family networks and facilitate income and consumption smoothing (Rosenzweig, 1998, 1993). On the other hand, an economic crisis may be associated with delayed marriage. The search for a spouse may be longer and more costly in a period of uncertainty since wage declines and reduced economic prospects make partners less marriageable. Further, females may delay marriage so that childbearing can be postponed, particularly in societies found in Eastern Europe where first births follow soon after marriage (Nobles and Buttenheim, 2006).

To capture the extent of the crisis (and subsequent recovery), the specific measures of macroeconomic conditions included in the analysis are the natural log of per capita gross domestic product (GDP) and a set of dummy variables representing varying levels of inflation 
(less than 5 per cent, between 5 and 25 per cent, between 25 and 100 per cent, and greater than 100 per cent). The figures which cover the transitional period of the 1990s were obtained from the World Bank ${ }^{5}$, whilst those relating to the communist period of the 1980s were taken from estimates made by the Central Intelligence Agency (CIA). ${ }^{6}$

As Table A2 shows, during the transitional period of the late-80s and early-90s, virtually all of the Eastern European countries included in our sample experienced huge declines in real GDP per capita. Further, eight of the twelve countries featured in Table A3 were subject to inflation of greater than 100 per cent in several years during the 1990s.

\subsubsection{Economic and social development}

Female enrolment in higher education is included as a control since the opportunity cost of completing studies in a marital setting may be high. Further, once education is completed, the opportunity cost of marriage and related child bearing is higher for more educated female workers. Indeed, a huge expansion of female enrolment in higher education in Eastern Europe took place following the collapse of communism.

Table A4 shows the percentage of females aged 20-24 who were enrolled in university education in 1980 and 1995 (UNESCO). Although there is a fairly large amount of missing data for this variable, the table does highlight the rapid growth in female participation in university

\footnotetext{
${ }^{5}$ Levine and Staiger (2004) note that it is difficult to obtain data for separate regions within a country, for example, the former German Demographic Republic and the former Czechoslovakia. Separate estimates for the German eastern regions of the level of GDP were able to be obtained, but for previous years, we follow Levine and Staiger (2004) and calculate the level of GDP using the more recent data combined with CIA estimates of GDP growth rates in earlier years. Inflation data for 1992 onwards were taken from the German Statistical Office and 1980 to 1989 data were obtained from CIA estimates. Data for 1990 and 1991 are missing. For the Czech and Slovak Republics, separate GDP figures over the 1984 to 1997 period were obtained from the World Bank, but for previous years, we again follow Levine and Staiger (2004) and assign the GDP growth rates from the combined Czechoslovakia to the 1984 levels of GDP to project backward. It is also assumed that inflation in the two republics were the same prior to their separation.

${ }^{6}$ Some countries and years have missing data for these macroeconomic variables, even using the CIA estimates. To include these countries in the analysis, we follow Levine and Staiger (2004) and add dummy variables for both GDP and inflation measures to indicate whether or not these data are missing.
} 
education in the regions. For example, Bulgaria, Hungary, and Poland have all experienced more than 100 per cent increases in female enrolment at universities. The only country in the sample which has observed a decline is Lithuania. Between 1985 and 1995, female enrolment at universities declined by more than 25 per cent.

A measure of urbanization (the proportion of people living in urban areas) was also included as a control in the analysis. Economic development may be expected to change the benefits and costs of marriage. For example, urbanization may generate new economic opportunities that provide an attractive alternative to early marriage. On the other hand, urbanization may also lower search costs leading to an increase in early marriage.

Table A5 shows that most of the Eastern European countries have experienced increased urbanization over the 1982 to 1997 period. The greatest increases in urbanization were experienced by Romania (13.4 per cent) and Hungary (11.3 per cent). Three countries in the sample (Estonia, GDR, and Moldova) observed small declines in urbanization.

\subsubsection{Marriage market conditions}

To capture the demographic availability of potential male spouses, the female-to-male population ratio in each country is included as a control. Theory would suggest that the probability of a female being married increases directly with the demographic supply of men to wed. Therefore, one should expect that the higher the female-to-male population ratio, the lower the female marriage rate. Table A6 shows the respective ratios between 1980 and 1996 for each Eastern European country included in the sample. Although there appears to be little variation across countries and through time, it is noticeable that in virtually all countries the older age groups (35 to 39 and 40 to 44 ) have female-to-male population ratios greater than one, indicating 
that there is an excess supply of women. Of course, this female-to-male population ratio represents only a crude approximation on two grounds. First, females typically marry older men and second, it is the eligible sex ratio (in terms of unmarried men and women) that matters most for the marriage market and is the theoretically correct measure, adjusted for differences in age at marriage. Unfortunately, it is not possible to obtain data on the latter.

Divorce laws were controlled for in the analysis since they too might be expected to affect entry into marriage. On the one hand, liberal divorce laws might encourage marriage since the law acts as a cheap form of 'insurance policy' should a marriage prove to an unhappy one. In other words, liberal divorce laws reduce the cost of exiting an unhappy marriage, so individuals may be encouraged to enter marriage more easily, particularly those who plan to have children (Alesina and Giuliano, 2007). On the other hand, liberal divorce laws may reduce the incentives for spouses to undertake marriage-specific investment, such as buying a house together (Stevenson, 2007). In turn, this will reduce the ex ante value of marriage and reduce marriage rates, all else equal. ${ }^{7}$

In this study, the following two-fold categorisation of divorce laws is adopted:

(1) Strict, institutionalised divorce laws - divorce permitted on the grounds of fault or other major disruption of marital life. Institutionalisation of marriage remains the leading principle, and the divorce process is hard and lengthy;

(2) Less strict, more individual-based divorce laws - divorce permitted on grounds of less restrictive legislation. Shows more understanding for the will of the spouses.

\footnotetext{
${ }^{7}$ Empirical evidence from the United States suggests that the adoption of unilateral divorce laws by many states in the 1970s has led to a significant and permanent decline in marriage rates (see Brinig and Grafton, 1994; Rasul, 2003).
} 
Data on divorce laws of each country were obtained from Martiny and Schwab (2003), Todorova (2003), Antokolskaia (2003), Weiss and Szeibert (2003), Maczynski and Sokolowski (2003), Harkonen and Dronkers (2006), the Max Planck Institute for Demographic Research, and through direct correspondence with legal experts in Eastern Europe. Table A7 shows that throughout the period under study, the majority of the Eastern European countries included in the sample have operated under Category (2) divorce laws. However, Bulgaria, the former GDR, and Romania experienced switches in divorce laws over the study period. In Bulgaria, the 1985 Family Code restored fault as a ground for divorce that represents a shift to Category (1) in the divorce coding. Meanwhile, in Romania, the 1993 Family Code introduced no-fault divorce, that represents a movement into Category (2).

The case of the former GDR is less straightforward. Between 1949 and 1990, the former GDR and West Germany followed widely differing approaches to divorce laws. Engelhardt et al. (2002) note that the combination of low costs, shorter waiting times, and greater simplicity of the procedure meant that divorce in East Germany was less stigmatizing and stress-producing compared to West Germany. Following unification, however, all divorce laws in the West were made applicable in the territory of the East. Whilst it would be incorrect to argue that this uniform divorce law is strict and institutionalised per se, for the purpose of this analysis it is reasonable to assume that the ex-GDR's adoption of West German divorce law in 1990 represented a shift toward a more restrictive divorce law regime.

Descriptive statistics for the variables used in the analysis that follows are found in Table 3. Several important econometric issues will now be addressed. 


\subsubsection{Econometric methodology}

The data used in the analysis are a panel of 208 observations that include twelve Eastern European countries for the years 1980 through 1997. Given that the data have time series and cross-section components, the analysis relies on changes in the legal status of abortion laws on marriage rates in these twelve countries. In the model specifications employed in the analysis, country fixed-effects are included to control for time-invariant differences in marriage rates across countries. These differences may relate, for example, to history, culture and other institutional arrangements. Time fixed-effects are also included to control for year-over-year changes common to each country. For instance, the timing of the decline and collapse of the Soviet Union undoubtedly had an impact on the twelve countries included in the study's sample.

To capture unobservable factors that may be evolving over time at different paces in different countries, country-specific trends are included in two model specifications. One potential criticism of this approach, however, is that such models might "overfit" the data, thereby reducing the power of the analysis (Blank, 2001). The results are presented both with and without these trends to examine the sensitivity of their inclusion. In models without these trends, identification is provided by those countries that changed their abortion laws over the period under study. In models with the trends, identification is based on the discrete nature of the change in abortion laws and the change in marital outcomes right around the time of the change in abortion laws. The following model was estimated using OLS:

$$
\begin{gathered}
\text { mrate }_{i, t}=\alpha+\beta_{1} \text { restrict }_{i, t}+\beta_{2} \text { onreq }_{i, t}+\gamma_{1} \text { GDP }_{i, t}+\gamma_{2} \text { inf } \text { lation }_{i, t}+\gamma_{3} \text { femenroll }_{i, t}+\gamma_{4} \text { urban }_{i, t}+ \\
\gamma_{5} \text { year }_{t}+\gamma_{6} \text { Country }_{i}+\gamma_{7} \text { trend }_{i}+\varepsilon
\end{gathered}
$$

where mrate is the female first-marriage rate for the different age categories for country $i$ in year $t$; restrict and onreq are indicator variables that equal one if the country had a restrictive 
abortion law or abortion available on request respectively for country $i$ and year $t$; GDP, inflation, femenroll, and urban are the GDP per capita, the inflation rate categorical dummy variables, the female university enrolment rate and the percentage of the population living in urban areas, respectively, for country $i$ in year $t$. Finally, year, country and trend are the year dummies, the country dummies and the country-specific trends (either linear or quadratic).

The estimation of each model assumes that any switch in abortion laws was exogenous to the differences across countries in social problems that were occurring at the same time and that may also have been associated with changes in marriage rates. It is possible that these social problems that were largely borne out of the economic transition process partly drove countries with restrictive abortion laws to change them in response to, for example, greater fertility control. However, the timing of the changes in abortion laws provides some variation in policies across countries that are not directly related to the period of the most dramatic social turmoil.

In all specifications, the omitted abortion law dummy is 'medical and social conditions', so the results are interpreted as the effect of imposing severe or liberal abortion restrictions relative to having a more moderate regime in place.

\section{Results}

\subsection{Main findings}

The effect of abortion's legal status on marriage rates of females for different age groups was examined in the empirical analysis. Table 3 presents estimates from models where the dependent variable is the first marriage rate of females aged 15 to 19 in Eastern Europe. The specification shown in Column 1 includes two abortion law dummies (representing 'strict' and 'liberal’ laws), macroeconomic conditions, and country and year fixed effects. Columns 2 and 3 
add linear and quadratic trends respectively, thus accounting for time-varying country-specific factors that may be related to both marriage rates and abortion law reforms. Column 4 adds controls that capture measures of economic and social development as well as marriage market conditions.

Columns 1 and 4 indicate that the marriage rate is lower in countries where abortion is available upon request compared to countries in which abortion is only available for medical and social conditions. Estimates from both specifications indicate that liberal abortion laws decrease marriage rates among teenagers by around 50 marriages per 1000 women. This seems to lend support to the Akerlof et al. (1996) theory discussed earlier, which suggests that a switch to more liberal abortion laws will lead to a decline in shotgun weddings. However, the introduction of country-specific trends in Columns 2 and 3 results in a change in the sign of the coefficient, and remains statistically significant in the specification with linear trends.

Meanwhile, the results reported in Tables 4 and 5 for the 'twenty-somethings' reveal a remarkably consistent story. Across all specifications, the coefficient on the liberal abortion law dummy is positive and strongly statistically significant. For females aged 20 to 24, the effect of imposing a liberal abortion law is estimated at 17.5 to 62.2 additional marriages per 1000 women, whilst for those aged 25 to 29 , the impact is estimated at 9.5 to 27.7 additional marriages.

Table 6 shows that for females aged 30 to 34, the adoption of liberal abortion laws in which abortion is available upon request also increases marriage rates relative to a regime where it is available for medical and social reasons only. However, the size of the coefficient is fairly small across all specifications and the introduction of country-specific linear trends (Column 2) lowers the estimate to the point where it is no longer statistically significant. The coefficients on 
the abortion law dummies for those females aged 35 to 39 and 40 to 44 (shown in Tables 7 and 8 respectively) are positive and statistically significant in Columns 1 and 4, but are sensitive to the inclusion of both country-specific linear and quadratic trends.

Table 7 also shows that, for females aged 35 to 39, the coefficient on the strict abortion dummy is positive and statistically significant in Columns 1 to 3 , indicating that marriage rates for this age group increase following the adoption of laws where abortion is only available to save the mother's life or for other specific medical reasons. This may be consistent with expectations that shotgun weddings become more prevalent when abortion laws are tightened in a country. Lack of precision of these estimates may be due to the fact that overall marriage rates are quite low for females over thirty leaving less variation to identify from.

Turning to the findings for the controls used in the analysis, a number of broadly consistent results emerge. In terms of the macroeconomic conditions, greater levels of GDP per capita are generally associated with higher female first marriage rates. Economic growth is likely to be accompanied by employment creation and may therefore imply some improvement in the pool of economically attractive men for women to marry. In addition, high rates of inflation (in particular, greater than 100 per cent) tend to be associated with higher female first marriage rates compared to low rates of inflation (less than 5 per cent). Hyperinflation may be a reflection of an economic crisis that may, as noted earlier, increase the attractiveness of marriage as a means of pooling resources and insuring against loss.

As for the measures of economic and social development, higher levels of female enrolment in university education are, as expected, associated with lower first marriage rates. However, there are asymmetrical effects observed across age groups relating to the impact of urbanization on marriage rates. A greater rate of urbanization is associated with higher marriage 
rates for females aged between 15 and 24, but lower marriage rates for those aged between 25 and 44. One possible explanation is that greater urbanization implies a larger potential supply of male spouses in the marriage market, thus resulting in females marrying at an earlier age.

Finally, turning to marriage market conditions, the findings suggest that restrictive divorce laws are associated with higher marriage rates for females aged between 30 and 44 . The implication here is that an older woman in particular may feel more secure about entering marriage if the divorce law regime reduces the probability of her being an unwilling party to divorce. This is also related to the more general idea that a woman tends to be valued less in the remarriage market than a male of similar age (Cohen, 1987).

Less easily explained are the results relating to the study's other measure of marriage market conditions, namely, female-to-male population ratios. Across several age groups, statistically significant coefficients are reported, but the signs are not all in the same direction. For example, for females aged 20-24, a higher ratio is associated with lower female marriage rates, which is in line with expectations. On the other hand, for those aged 15-19, 20-24 and 3034, a higher ratio is associated with higher marriage rates, which goes against economic theory. However, given that this control is only a very crude approximation of the female-to-male population ratio, it is perhaps not surprising that it is not a strongly performing variable due to the measurement issues noted earlier.

In summary, the results presented in this section provide strong evidence that the status of abortion laws has a large impact on the female marriage rate. In particular, the estimates reported for 'twenty-something' females indicate that making abortion available upon request is associated with an increase in the marriage rate. This lends some support to the theory that suggests that, under a liberal abortion regime, females may adopt a strategy of 'learning through 
pregnancy' to separate 'Dads' from 'Cads'. These results would also appear to be consistent with the findings of Levine and Staiger (2004) who report that, over the same 1980 to 1997 period in Eastern Europe, a switch from moderate restrictions to abortion available upon request was associated with no change in births despite large increases in abortions, indicating that pregnancies increased following more liberal access to abortion. As argued earlier, if more pregnancies take place, some of these will turn into marriage.

\subsection{Robustness checks}

One concern with the model specifications adopted in the analysis is that they do not explicitly capture the collapse of communism that was common across the twelve countries included in the study's sample. In an attempt to understand the extent to which this mattered for female marriage rates, all four specifications were modified to include either a level shift "political shock" dummy (set to 1 from 1990 onwards) or a time trend (set to 0 until 1990 and

then incrementing onwards). The results (not shown) were not overly sensitive to the inclusion of these dummy variables.

Another worry might be that only a few countries are driving most of the results. Therefore, the regressions were estimated dropping one individual country at a time and the general results did not change significantly. However, for the teenage age group, the exclusion of Hungary from the sample resulted in the sign on the 'liberal' abortion dummy being negative across all model specifications, although conventional levels of significance were still not reached once country-specific trends were added.

Finally, the initial estimation strategy in this study only captures a discrete series break in abortion laws. One potential problem with this methodology is that it may confound pre-existing 
trends in female marriage rates with the dynamic response of a policy shock. To account for this response to the regime change, the four model specifications were modified to include dummies for the 'strict' abortion law having been effective for up to two years and the 'liberal' abortion law having been in place for up to three years. These dummies capture the dynamic response of marriage rates to abortion law changes while the country-specific trends identify pre-existing trends.

Tables A8 to A10 of the Appendix report the dynamics of abortion law changes where the reforms are allowed to have time-varying effects. As with the 'discrete jump approach' adopted in the initial analysis, the specifications all include year and country fixed effects, as well as country-specific linear and quadratic trends. The results are broadly similar to those obtained from the discrete jump approach with the strongest effects being observed for the 'liberal’ abortion law dummies.

Yet, there are noticeable differences across the age groups under study. Table A9 shows that making abortion available upon request has a positive and statistically significant effect on marriage rates for females aged between 25 and 29 during the first year of reform, but the magnitude of the effect diminishes by the end of the first three years. The results for those aged between 30 and 44 from the discrete jump approach were not always robust to the inclusion of country-specific trends. However, as Tables A9 and A10, the coefficient on the 'liberal' abortion law dummy is positive and statistically significant across all specifications during the three years following reform. For example, the effect of making abortion available on request for 35 to 39 year-olds is estimated at 3.48 to 6.00 female marriages per 1000 women and at 0.69 to 1.57 marriages for 40 to 44 year-olds. 
In summary, the robustness checks and dynamic specifications examined in this section appear to support the main findings of this study: a switch to a more liberal abortion law regime is associated with an increase in marriage rates for non-teenage females.

\section{Conclusions}

In recent years, a growing number of studies have begun to examine the ways in which access to abortion might affect various social and economic phenomena. Whilst the study by Donohue and Levitt (2001) exploring the relationship between abortion legalization and crime rates in the United States is undoubtedly the most well-known and controversial, several studies have also indicated that the availability of abortion may change the sexual behaviour of women. In turn, this has ramifications for other related issues such as the prevalence of sexually transmitted diseases and incidence of 'shotgun weddings'. Much of this work focuses upon the United States, where a variety of policy changes affecting abortion access have occurred over the past four decades. However, there have also been significant changes in abortion policy in other parts of the world, most notably in Eastern Europe, and this study is the first of its kind to investigate how adoption of new abortion laws in the region may have affected female entry into marriage. Eastern Europe provides an extremely useful environment in which to undertake the analysis since the changes in abortion policy that took place in the late 1980s and early 1990s were both extensive and varied.

Previous studies from the United States had found that liberalization of abortion laws is associated with a decline in the marriage rate among females. Akerlof et al. (1996), for instance, theorized that, as a precondition for marital sex, a woman is no longer able to insist upon a marriage promise in the event of pregnancy, while a man feels less obligated to marry his partner 
under these circumstances given that fertility is now a decision on her part. Our study proposed that the liberalization of abortion laws has the potential to raise female marriage rates since it lowers the cost to a woman of using pregnancy as a mechanism to screen 'Dads' from 'Cads'. The empirical analysis that followed revealed that the movement from an abortion regime with only moderate restrictions to one in which abortion is available upon request appeared to raise marriage rates among non-teenage females in Eastern Europe. Although it would be bold to claim that the majority of women adopted this strategy across the region, the results for those aged 25 to 29 in particular were sufficiently robust to suggest that there is a possible role for this competing theory of abortion access and marriage. 


\section{References}

Akerlof, G., J.Yellen, and M. Katz (1996), ‘An Analysis of Out-of-Wedlock Childbearing in the United States’, Quarterly Journal of Economics, 111(2): 277-317.

Angrist, Joshua D. and William Evans (1999), 'Schooling and Labor Market Consequences of the 1970 State Abortion Reforms’, in Polachek, Solomon W. (ed.), Research in Labor Economics, 18, 75-113.

Antokolskaia, M. (2003), 'Grounds for divorce and maintenance between former spouses Russia’, in K. Boele-Woelki, B. Braat, and I. Curry-Sumner, European Family Law in Action, Volume 1 - Grounds for Divorce, Commission on European Family Law.

Alesina, A. and P. Giuliana (2007), 'Divorce, Fertility and the Value of Marriage', Harvard Institute of Economic Research, Discussion Paper No. 2136.

Brinig, M.F. and S.M. Grafton (1994), 'Marriage and opportunism', Journal of Legal Studies, 23, 869-894.

Chiappori, P. and S. Oreffice (2008), 'Birth Control and Female Empowerment: An Equilibrium Analysis’, Journal of Political Economy, 116(1): 113-40.

Choo, E. and A. Siow (2006), 'Who Marries Whom and Why?', Journal of Political Economy 114, 1, 176-201.

Codagnone, C. (1998), 'New Migration and Migration Politics in Post-Soviet Russia', Ethnobarameter, working paper series no. 2.

Cohen, L. (1987), 'Marriage, Divorce, and Quasi Rents; or 'I Gave Him the Best Years of My Life', Journal of Legal Studies, 26-303.

Donohue, J.J. III and S.D. Levitt (2001), 'The Impact of Legalized Abortion on Crime’, Quarterly Journal of Economics, 116 (2), 379-420.

Engelhardt, H., H. Trappe, and J. Dronkers (2002), 'Differences in Family Policy and the Intergenerational Transmission of Divorce: A Comparison between the Former East and West Germany’, Max Planck Institute for Demographic Research, working paper No. 8.

Goldin, C. and L. Katz (2002), ‘The Power of the Pill: Oral Contraceptives and Women’s Career and Marriage Decisions’, Journal of Political Economy, 110(4): 730-70. 
Harnkonen, J. and J. Dronkers (2006), 'Stability and Change in the Effects of Female Educational Attainment on the Risk of Union Dissolution: A Seventeen Country Comparison', working paper, European University Institute.

Hrusakova, M. (2003), 'Grounds for divorce and maintenance between former spouses - Czech Republic', K. Boele-Woelki, B. Braat, and I. Curry-Sumner, European Family Law in Action, Volume 1 - Grounds for Divorce, Commission on European Family Law.

Kane, T. and D. Staiger (1996), 'Teen Motherhood and Abortion Access', Quarterly Journal of Economics, 111 (1996): 467-506.

Klick, J. and T. Stratman (2006), 'The Effect of Abortion Legalization on Sexual Behavior: Evidence from Sexually Transmitted Diseases', working paper.

Levine, P. (2000), 'The Sexual Activity and Birth Control Use of American Teenagers', NBER working paper, no. 7601.

Levine, P. and D. Staiger (2004), 'Abortion Policy and Fertility Outcomes: The Eastern European Experience’, Journal of Law and Economics, 47(1):223-243.

Maczynski, A. and T. Sokolowski (2003), 'Grounds for divorce and maintenance between former spouses - Poland', in K. Boele-Woelki, B. Braat, and I. Curry-Sumner, European Family Law in Action, Volume 1 - Grounds for Divorce, Commission on European Family Law.

Martiny D. and D. Schwab (2003), 'Grounds for divorce and maintenance between former spouses - Germany', in K. Boele-Woelki, B. Braat, and I. Curry-Sumner, European Family Law in Action, Volume 1 - Grounds for Divorce, Commission on European Family Law.

Nobles, J. and A. Buttenheim (2006), 'Marriage in periods of crisis: Evidence from Indonesia', California Center for Population Research, University of California at Los Angeles, working paper

Norberg, K. (2003), 'Dads and Cads: Paternal Investment and Variation in the Human Sex Ratio at Birth', working paper.

Philipov, D. (2003), 'Major trends affecting families in Central and Eastern Europe', working paper, Vienna Institute of Demography

Posner, Richard A. (1992), Sex and Reason, Cambridge, MA: Harvard University Press. 
Rahman, A., L. Katzive, and S.K. Henshaw (1998) ‘A Global Review of Laws on Induced Abortion', International Family Planning Perspectives, 24: 56-64.

Rasul, I. (2003), 'The impact of divorce laws on marriage', working paper, University of Chicago Graduate School of Business.

Rosenzweig, M.R. (1988), 'Risk, implicit contracts and the family in rural areas in low-income countries’, Economic Journal, 98 (393), 1148-70.

Rosenzweig, M.R. (1993), ‘Women, insurance capital and education in rural India’, Journal of Human Resources, 28 (4), 735-58.

Rostgaard, T. (2004), 'Family support policy in Central and Eastern Europe - a decade and a half of transition’, UNESCO Early Childhood and Family Policy Series No. 8.

Todrova, T. (2003), 'Grounds for divorce and maintenance between former spouses - Bulgaria', in K. Boele -Woelki, B. Braat, and I. Curry-Sumner, European Family Law in Action, Volume 1 - Grounds for Divorce, Commission on European Family Law.

United Nations Population Division, Department of Economic and Social Affairs (1992) Abortion Policies: A Global Review. Volume 1: Afghanistan to France. New York: United Nations.

United Nations Population Division, Department of Economic and Social Affairs (1994), Abortion Policies: A Global Review. Volume 2: Gabon to Norway. New York: United Nations.

United Nations Population Division, Department of Economic and Social Affairs (1995), Abortion Policies: A Global Review. Volume 3: Oman to Zimbabwe. New York: United Nations.

United Nations Population Division, Department of Economic and Social Affairs (1999), World Abortion Policies 1999. New York: United Nations.

Weiss, E. and O. Szeibert (2003), 'Grounds for divorce and maintenance between former spouses - Hungary', in K. Boele-Woelki, B. Braat, and I. Curry-Sumner, European Family Law in Action, Volume 1 - Grounds for Divorce, Commission on European Family Law. 
Figure 2 First marriage rates for 25-29 year-old females in countries that did not liberalize abortion laws during the 1980 to 1997 period

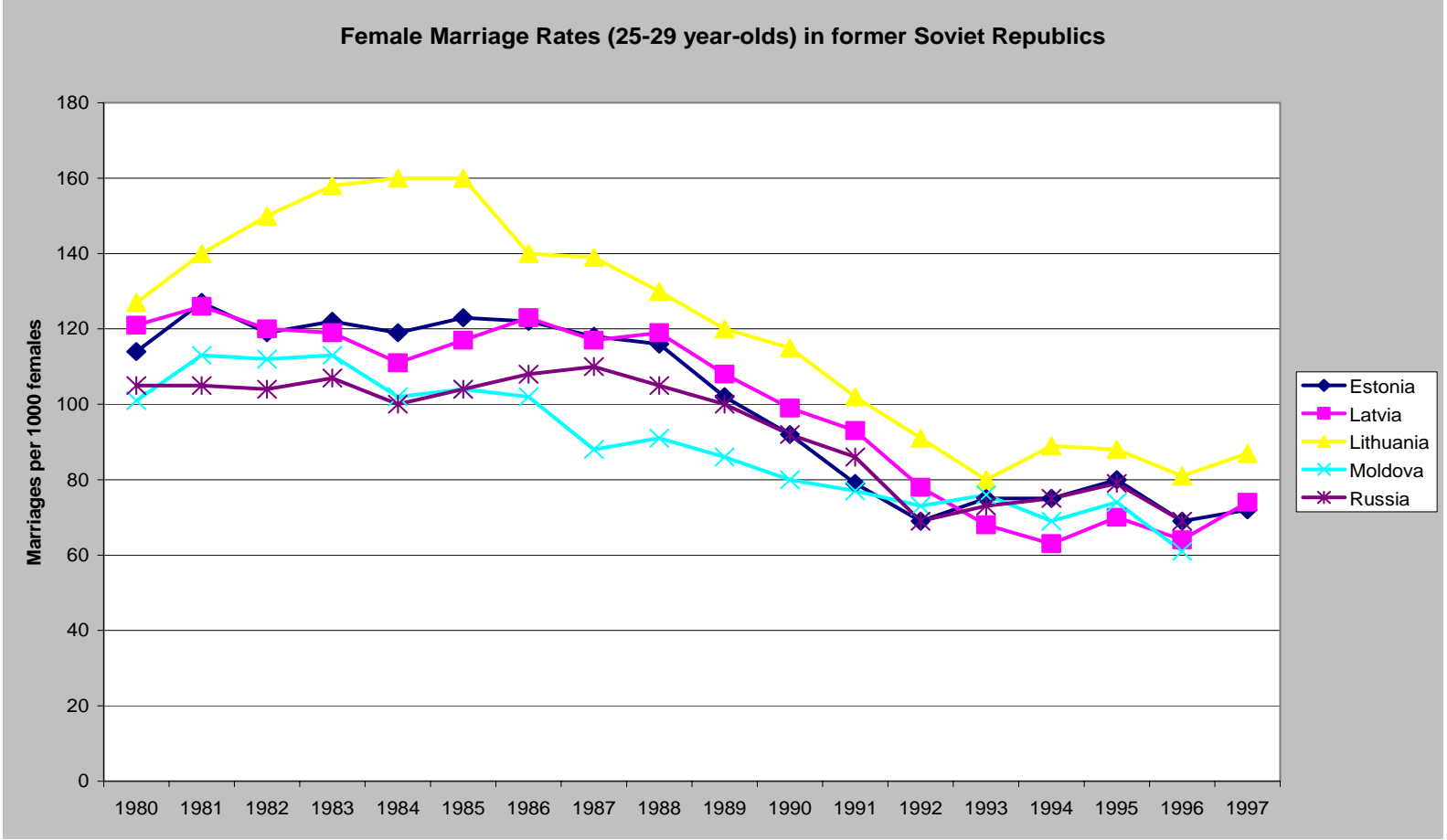

Figure 3 First marriage rates for 25-29 year-old females in countries that liberalized abortion laws during the 1980 to 1997 period

Female Marriage Rates (25-29 year olds) in Bulgaria, Czech Republic, Hungary, Romania, and Slovak Republic

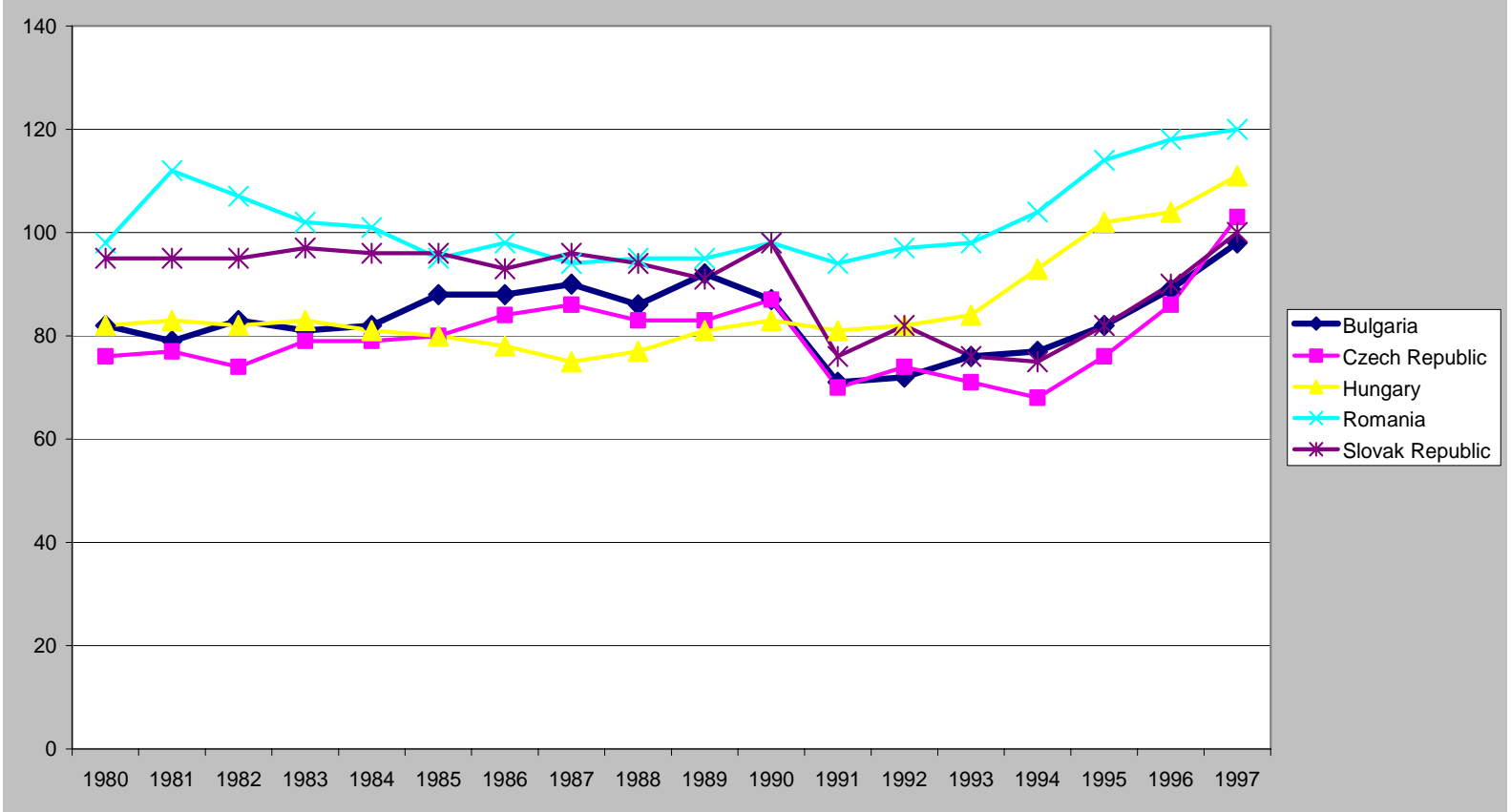


Table $1 \quad$ Weighted average values of outcome measures, by region

Eastern Europe $\quad$ Western Europe

\begin{tabular}{|l|c|c|c|c|}
\hline & $\mathbf{1 9 8 0}$ & $\mathbf{1 9 9 5}$ & $\mathbf{1 9 8 0}$ & $\mathbf{1 9 9 5}$ \\
\hline & & & & \\
\hline Female marriage rate (per 1000 women): & & & & \\
\hline Aged 15-19 & 334.5 & 261.8 & 153.2 & 33.3 \\
\hline Aged 20-24 & 398.7 & 338.5 & 382.8 & 196.7 \\
\hline Aged 25-29 & 101.7 & 90.7 & 137.3 & 228.1 \\
\hline Aged 30-34 & 30.9 & 23.8 & 34.1 & 82.4 \\
\hline Aged 35-39 & 27.9 & 9.2 & 12.1 & 25.1 \\
\hline Aged 40-44 & 5.1 & 4.3 & 6.1 & 7.8 \\
\hline
\end{tabular}

Source: Council of Europe 


\begin{tabular}{|l|c|c|c|c|}
\hline Variable & Mean & S.E. & Min. & Max. \\
\hline & & & & \\
\hline Female first marriage rate (15-19 year-olds) & 266.5 & 116.6 & 17.0 & 580.0 \\
\hline Female first marriage rate (20-24 year-olds) & 412.9 & 95.9 & 176.0 & 577.0 \\
\hline Female first marriage rate (25-29 year-olds) & 97.1 & 21.4 & 61.0 & 163.0 \\
\hline Female first marriage rate (30-34 year-olds) & 26.4 & 7.1 & 15.0 & 45.0 \\
\hline Female first marriage rate (35-39 year-olds) & 10.1 & 3.6 & 5.0 & 21.0 \\
\hline Female first marriage rate (40-44 year-olds) & 4.9 & 2.4 & 2.0 & 15.0 \\
\hline Legal to save mother's life or for other specific medical reasons & 0.06 & 0.2 & 0 & 1 \\
\hline Available upon request & 0.7 & 0.4 & 0 & 1 \\
\hline Log GDP per capita & 10.3 & 1.3 & 7.9 & 13.2 \\
\hline Inflation between 5\% and 25\% & 0.3 & 0.4 & 0 & 1 \\
\hline Inflation between 25\% and 100\% & 0.1 & 0.3 & 0 & 1 \\
\hline Female enrolment in university education & 14.7 & 15.0 & 0 & 52.8 \\
\hline Urbanization & 64.1 & 9.1 & 41.7 & 79.0 \\
\hline Female to male population ratio (15-44 years-old) & 0.98 & 0.02 & 0.91 & 1.16 \\
\hline Female to male population ratio (15-19 years-old) & 0.95 & 0.01 & 0.90 & 1.00 \\
\hline Female to male population ratio (20-24 years-old) & 0.95 & 0.02 & 0.87 & 1.07 \\
\hline Female to male population ratio (25-29 years-old) & 0.97 & 0.02 & 0.91 & 1.07 \\
\hline Female to male population ratio (30-34 years-old) & 1.03 & 0.61 & 0.93 & 9.73 \\
\hline Female to male population ratio (35-39 years-old) & 1.01 & 0.03 & 0.93 & 1.12 \\
\hline Female to male population ratio (40-44 years-old) & 1.04 & 0.04 & 0.94 & 1.14 \\
\hline Restrictive divorce laws & 0.15 & 0.36 & 0 & 1 \\
\hline
\end{tabular}


Table 3 OLS estimates of the effect of abortion laws on first marriage rates of females aged 15-19 in Eastern Europe

\begin{tabular}{|c|c|c|c|c|}
\hline & (1) & $(2)$ & (3) & (4) \\
\hline \multicolumn{5}{|l|}{ Abortion laws } \\
\hline $\begin{array}{l}\text { Legal to save mother's life or for other specific } \\
\text { medical reasons }{ }^{\text {a }}\end{array}$ & $17.6(14.8)$ & $12.2(19.1)$ & $0.71(17.2)$ & $11.2(17.4)$ \\
\hline Available upon request $^{\mathrm{a}}$ & $-53.7(13.5)^{* * *}$ & $21.5(11.0)^{* *}$ & $4.27(11.7)$ & $-51.8(16.7)^{* * *}$ \\
\hline \multicolumn{5}{|l|}{ Macroeconomic conditions } \\
\hline Log GDP per capita & $0.005(0.003)$ & $0.03(0.004)^{* * *}$ & $0.02(0.003) * * *$ & $0.02(0.01)^{* *}$ \\
\hline Inflation between $5 \%$ and $25 \%{ }^{b}$ & $29.4(10.1)^{* * *}$ & $10.4(6.63)$ & $2.08(5.88)$ & $35.7(11.2)^{* * *}$ \\
\hline Inflation between $25 \%$ and $100 \%{ }^{b}$ & $33.1(16.0) * *$ & $19.6(11.4)^{*}$ & $11.5(10.5)$ & $32.3(15.2)^{* * *}$ \\
\hline Inflation greater than $100 \%^{b}$ & $70.1(19.3)^{* * *}$ & $46.8(13.1)^{* * *}$ & $34.5(11.6)^{* * *}$ & $69.1(17.7)^{* * *}$ \\
\hline \multicolumn{5}{|l|}{ Economic and social development } \\
\hline Female enrolment in university education & & & & $0.15(0.34)$ \\
\hline Urbanization & & & & $7.64(3.53)^{* *}$ \\
\hline \multicolumn{5}{|l|}{ Marriage market conditions } \\
\hline Female to male population ratio (15-19) & & & & $829.3(367.8) * *$ \\
\hline Restrictive divorce laws ${ }^{c}$ & & & & $-20.8(15.5)$ \\
\hline Country-specific linear trends & No & Yes & No & No \\
\hline Country-specific quadratic trends & No & No & Yes & No \\
\hline $\mathrm{R}^{2}$ & 0.87 & 0.96 & 0.96 & 0.91 \\
\hline Sample size & 208 & 208 & 208 & 172 \\
\hline
\end{tabular}

The dependent variable is the first female marriage rate per 1000 women aged 15-19. All models include county and year fixed effects and dummy variables indicating whether GDP and inflation data are missing. They are also weighted by the size of the relevant population. Standard errors are reported in parentheses and are corrected for heteroscedasticity. ${ }^{\text {a }}$ omitted category is 'legal for medical or social reasons', ${ }^{\text {b }}$ omitted category is 'inflation less than 5\%', ' omitted category is unrestrictive divorce laws.

*** $\mathrm{p}<0.01 * * \mathrm{p}<0.05 * \mathrm{p}<0.10$ (two-tailed tests, under $\mathrm{H}_{0}: \beta=0$ ) 
Table 4 OLS estimates of the effect of abortion laws on first marriage rates of females aged 20-24 in Eastern Europe

\begin{tabular}{|c|c|c|c|c|}
\hline & $(1)$ & $(2)$ & $(3)$ & $(4)$ \\
\hline $\begin{array}{l}\text { Legal to save mother's life or for other } \\
\text { specific medical reasons }{ }^{\text {a }}\end{array}$ & $-0.19(15.3)$ & $-22.6(16.9)$ & $-6.33(17.2)$ & $-34.5(12.6)^{* * *}$ \\
\hline Available upon request ${ }^{a}$ & $62.2(9.48)^{* * *}$ & $22.4(10.7)^{* * *}$ & $41.5(11.5)^{* * *}$ & $17.5(9.24)^{*}$ \\
\hline \multicolumn{5}{|l|}{ Macroeconomic conditions } \\
\hline Log GDP per capita & $-0.003(0.003)$ & $0.01(0.01)$ & 3E-04 (0.005) & $0.04(0.007)^{* * *}$ \\
\hline Inflation greater than $100 \%{ }^{b}$ & $14.6(14.4)$ & $28.1(12.7)^{* *}$ & $33.2(13.1)^{* * *}$ & $0.84(11.2)$ \\
\hline \multicolumn{5}{|l|}{ Economic and social development } \\
\hline Female enrolment in university education & & & & $-0.47(0.22)^{* *}$ \\
\hline Urbanization & & & & $6.95(1.73)^{* * *}$ \\
\hline \multicolumn{5}{|l|}{ Marriage market conditions } \\
\hline Country-specific quadratic trends & No & No & Yes & No \\
\hline $\mathrm{R}^{2}$ & 0.90 & 0.94 & 0.93 & 0.94 \\
\hline Sample size & 208 & 208 & 208 & 172 \\
\hline
\end{tabular}

The dependent variable is the first female marriage rate per 1000 women aged 20-24. All models include county and year fixed effects and dummy variables indicating whether GDP and inflation data are missing. They are also weighted by the size of the relevant population. Standard errors are reported in parentheses and are corrected for heteroscedasticity. a omitted category is 'legal for medical or social reasons', ${ }^{\mathrm{b}}$ omitted category is 'inflation less than 5\%', ' omitted category is unrestrictive divorce laws.

*** $\mathrm{p}<0.01 * * \mathrm{p}<0.05 * \mathrm{p}<0.10$ (two-tailed tests, under $\mathrm{H}_{0}: \beta=0$ ) 
Table 5 OLS estimates of the effect of abortion laws on first marriage rates of females aged 25-29 in Eastern Europe

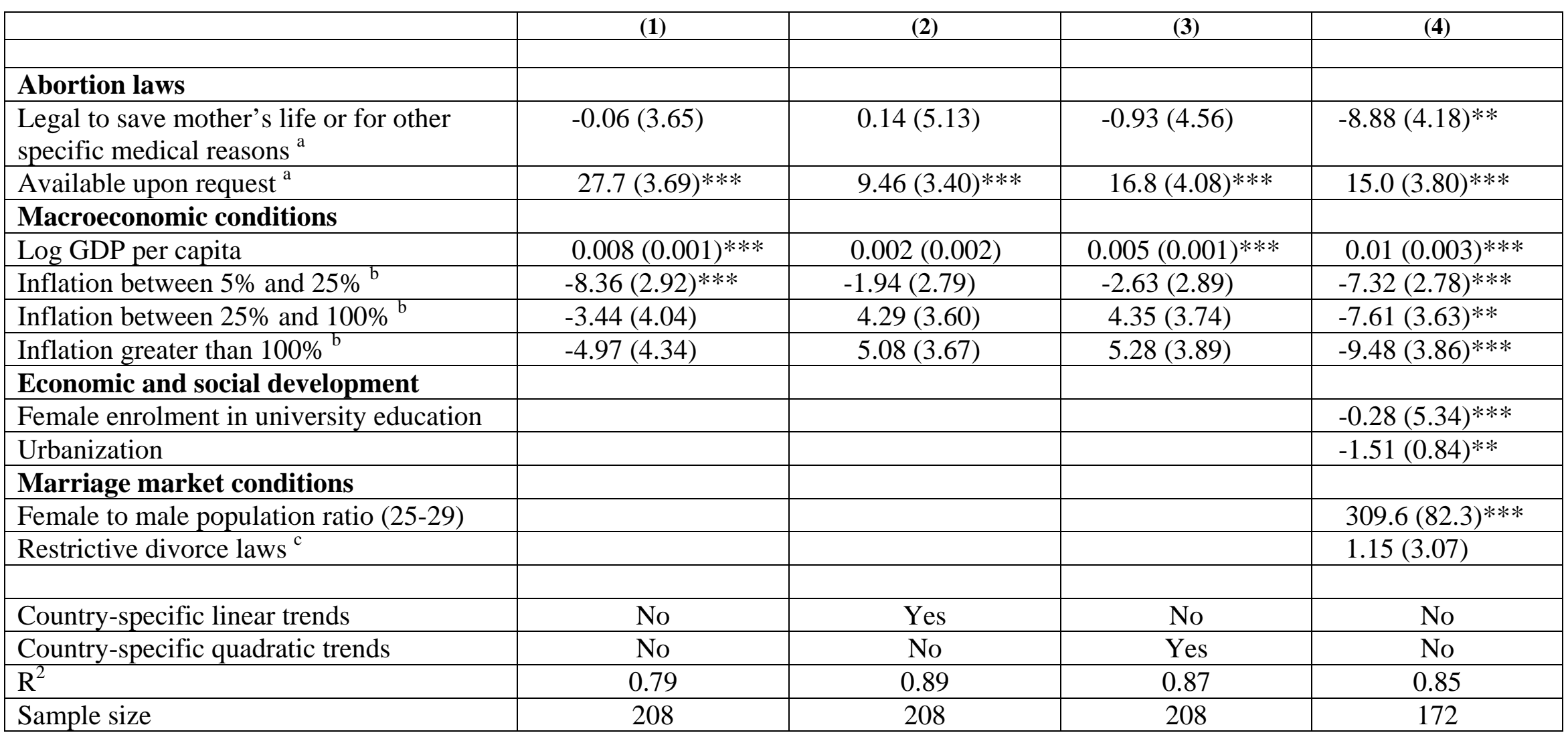

The dependent variable is the first female marriage rate per 1000 women aged 25-29. All models include county and year fixed effects and dummy variables indicating whether GDP and inflation data are missing. They are also weighted by the size of the relevant population. Standard errors are reported in parentheses and are corrected for heteroscedasticity. a omitted category is 'legal for medical or social reasons', ${ }^{\mathrm{b}}$ omitted category is 'inflation less than 5\%', ' omitted category is unrestrictive divorce laws.

*** $\mathrm{p}<0.01 * * \mathrm{p}<0.05 * \mathrm{p}<0.10$ (two-tailed tests, under $\mathrm{H}_{0}: \beta=0$ ) 
Table 6 OLS estimates of the effect of abortion laws on first marriage rates of females aged 30-34 in Eastern Europe

\begin{tabular}{|c|c|c|c|c|}
\hline & (1) & $(2)$ & (3) & (4) \\
\hline $\begin{array}{l}\text { Legal to save mother's life or for other } \\
\text { specific medical reasons }{ }^{\text {a }}\end{array}$ & $1.39(0.95)$ & $1.85(1.22)$ & $0.83(1.07)$ & $-2.38(1.25) * *$ \\
\hline Available upon request $^{\mathrm{a}}$ & $6.53(0.92) * * *$ & $0.89(0.88)$ & $2.73(1.07)^{* * *}$ & $3.15(0.90)^{* * *}$ \\
\hline \multicolumn{5}{|l|}{ Macroeconomic conditions } \\
\hline Log GDP per capita & $0.003(4 \mathrm{E}-04) * * *$ & $0.001(5 \mathrm{E}-04) * * *$ & $0.002(4 \mathrm{E}-04) * * *$ & $0.006(8 \mathrm{E}-04)^{* * *}$ \\
\hline Inflation greater than $100 \%^{b}$ & $0.12(1.09)$ & $1.64(0.98) *$ & $1.94(1.07)^{*}$ & $-1.67(1.13)$ \\
\hline \multicolumn{5}{|l|}{ Economic and social development } \\
\hline Female enrolment in university education & & & & $-0.07(0.02)^{* * *}$ \\
\hline Urbanization & & & & $-0.42(0.18)^{* *}$ \\
\hline \multicolumn{5}{|l|}{ Marriage market conditions } \\
\hline Country-specific quadratic trends & No & No & Yes & No \\
\hline $\mathrm{R}^{2}$ & 0.87 & 0.92 & 0.90 & 0.91 \\
\hline Sample size & 208 & 208 & 208 & 172 \\
\hline
\end{tabular}

The dependent variable is the first female marriage rate per 1000 women aged 30-34. All models include county and year fixed effects and dummy variables indicating whether GDP and inflation data are missing. They are also weighted by the size of the relevant population. Standard errors are reported in parentheses and are corrected for heteroscedasticity. ${ }^{\text {a }}$ omitted category is 'legal for medical or social reasons', ${ }^{\text {b }}$ omitted category is 'inflation less than 5\%', ' omitted category is unrestrictive divorce laws.

*** $\mathrm{p}<0.01 * * \mathrm{p}<0.05 * \mathrm{p}<0.10$ (two-tailed tests, under $\mathrm{H}_{0}: \beta=0$ ) 
Table 7 OLS estimates of the effect of abortion laws on first marriage rates of females aged 35-39 in Eastern Europe

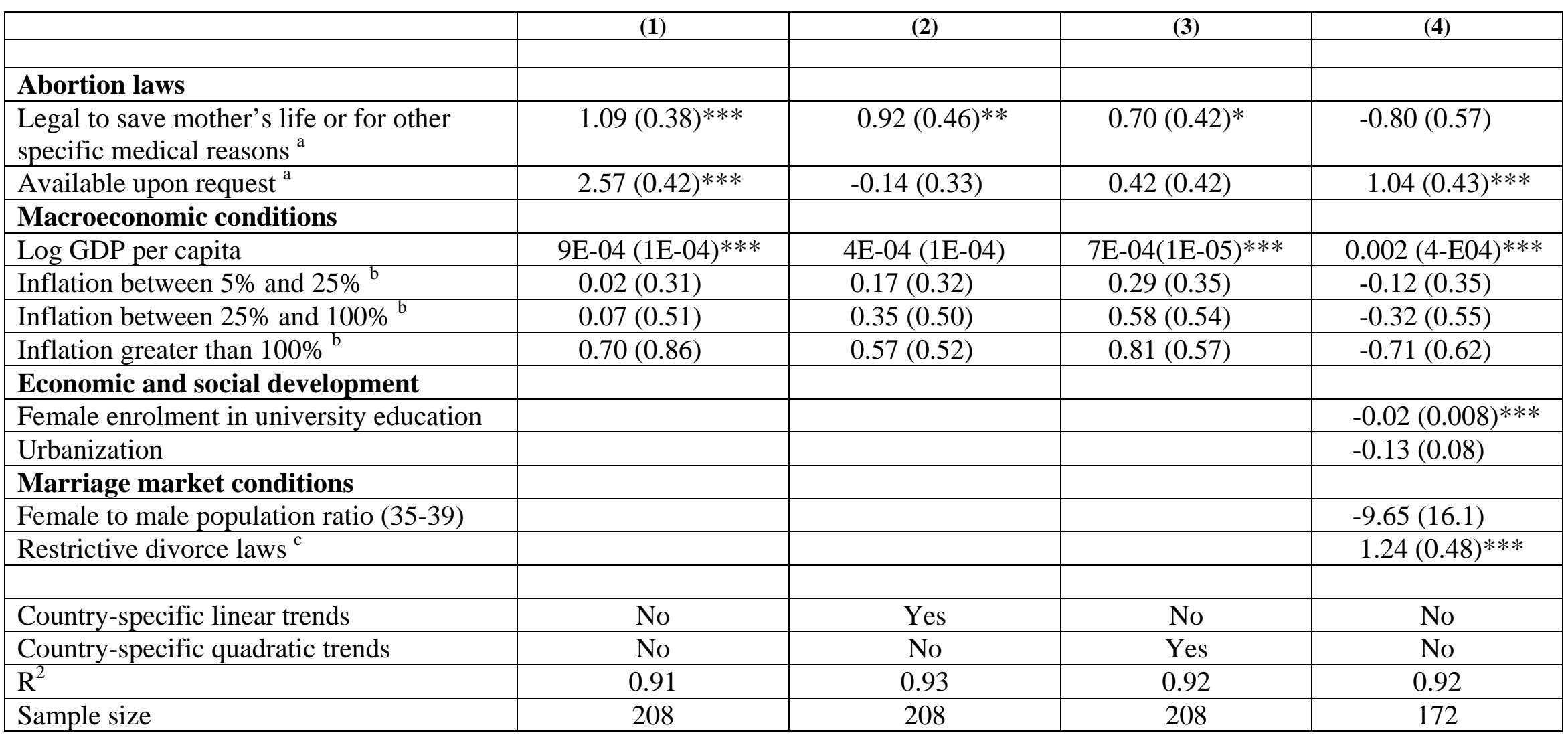

The dependent variable is the first female marriage rate per 1000 women aged 35-39. All models include county and year fixed effects and dummy variables indicating whether GDP and inflation data are missing. They are also weighted by the size of the relevant population. Standard errors are reported in parentheses and are corrected for heteroscedasticity. ${ }^{\text {a }}$ omitted category is 'legal for medical or social reasons', ${ }^{\text {b }}$ omitted category is 'inflation less than 5\%', ' omitted category is unrestrictive divorce laws.

*** $\mathrm{p}<0.01 * * \mathrm{p}<0.05 * \mathrm{p}<0.10$ (two-tailed tests, under $\mathrm{H}_{0}: \beta=0$ ) 
Table 8 OLS estimates of the effect of abortion laws on first marriage rates of females aged 40-44 in Eastern Europe

\begin{tabular}{|c|c|c|c|c|}
\hline & (1) & (2) & (3) & (4) \\
\hline \multicolumn{5}{|l|}{ Abortion laws } \\
\hline $\begin{array}{l}\text { Legal to save mother's life or for other } \\
\text { specific medical reasons }{ }^{\text {a }}\end{array}$ & $0.65(0.26)^{* * *}$ & $-0.17(0.35)$ & $-0.09(0.31)$ & $-0.64(0.35)^{*}$ \\
\hline Available upon request ${ }^{\mathrm{a}}$ & $1.71(0.29)^{* * *}$ & $-0.28(0.21)$ & $0.15(0.25)$ & $0.81(0.26)^{* * *}$ \\
\hline \multicolumn{5}{|l|}{ Macroeconomic conditions } \\
\hline Log GDP per capita & 5E-04 (1E-04)*** & 2E-04 (1E-04)** & $4 \mathrm{E}-04(1 \mathrm{E}-04) * * *$ & $0.001(2 \mathrm{E}-04) * * *$ \\
\hline Inflation greater than $100 \%{ }^{b}$ & $0.20(0.37)$ & $0.74(0.30)^{* * *}$ & $0.94(0.32)^{* * *}$ & $-0.14(0.37)$ \\
\hline \multicolumn{5}{|l|}{ Economic and social development } \\
\hline Female enrolment in university education & & & & $-0.01(0.006)^{* *}$ \\
\hline Urbanization & & & & $-0.16(0.06)^{* * *}$ \\
\hline \multicolumn{5}{|l|}{ Marriage market conditions } \\
\hline Country-specific quadratic trends & No & No & Yes & No \\
\hline $\mathrm{R}^{2}$ & 0.87 & 0.93 & 0.93 & 0.91 \\
\hline Sample size & 208 & 208 & 208 & 172 \\
\hline
\end{tabular}

The dependent variable is the first female marriage rate per 1000 women aged 40-44. All models include county and year fixed effects and dummy variables indicating whether GDP and inflation data are missing. They are also weighted by the size of the relevant population. Standard errors are reported in parentheses and are corrected for heteroscedasticity. ${ }^{\text {a }}$ omitted category is 'legal for medical or social reasons', ${ }^{\text {b }}$ omitted category is 'inflation less than 5\%', ' omitted category is unrestrictive divorce laws.

$$
\text { *** } \mathrm{p}<0.01 * * \mathrm{p}<0.05 * \mathrm{p}<0.10 \text { (two-tailed tests, under } \mathrm{H}_{0}: \beta=0 \text { ) }
$$


APPENDIX

Table A1 Abortion Laws in Eastern Europe (1980-1997)

\begin{tabular}{|c|c|c|c|c|c|c|}
\hline Country & $\begin{array}{l}\text { Years } \\
\text { Legalized }\end{array}$ & Description & $\begin{array}{l}\text { Legal Status of } \\
\text { Abortion }\end{array}$ & $\begin{array}{l}\text { Waiting } \\
\text { Period/ } \\
\text { Counselling }\end{array}$ & $\begin{array}{l}\text { Large } \\
\text { Cost } \\
\text { Subsidy }\end{array}$ & $\begin{array}{l}\text { Parental } \\
\text { Consent }\end{array}$ \\
\hline Bulgaria & $\begin{array}{l}1973-1989 \\
1990-\end{array}$ & $\begin{array}{l}\text { Legal for medical reasons or on request in the first } 10 \text { weeks of pregnancy for certain categories of women, like those with } 2 \text { or more } \\
\text { children } \\
\text { Legal on request in the first } 12 \text { weeks of pregnancy }\end{array}$ & $\begin{array}{l}\text { Medical/Social } \\
\text { On request }\end{array}$ & $\begin{array}{l}\mathrm{Y} \\
\mathrm{Y}\end{array}$ & $\begin{array}{l}\mathrm{Y} \\
\mathrm{Y}\end{array}$ & $\begin{array}{l}\mathrm{N} \\
\mathrm{N}\end{array}$ \\
\hline Czech Republic & $\begin{array}{l}1957-1986 \\
1987-\end{array}$ & $\begin{array}{l}\text { Legal for maternal health or social reasons in the first } 12 \text { weeks of pregnancy } \\
\text { Legal in the first } 12 \text { weeks of pregnancy on request and physician approval }\end{array}$ & $\begin{array}{l}\text { Medical/Social } \\
\text { On request }\end{array}$ & $\begin{array}{l}\mathrm{Y} \\
\mathrm{N}\end{array}$ & $\begin{array}{l}\mathrm{Y} \\
\mathrm{Y}\end{array}$ & $\begin{array}{l}\mathrm{N} \\
\mathrm{Y}\end{array}$ \\
\hline Estonia & $1955-$ & Legal on request in the first 12 weeks of pregnancy following consultation with doctor and notification of possible adverse consequences & On request & $\mathrm{Y}$ & $\mathrm{Y}$ & $\mathrm{N}$ \\
\hline GDR & $\begin{array}{l}1972-1992 \\
1993-\end{array}$ & $\begin{array}{l}\text { Legal on request in the first } 12 \text { weeks of pregnancy } \\
\text { Legal in the first } 12 \text { weeks of pregnancy after mandatory counselling and a 3-day waiting period; procedure is subsidised in majority of } \\
\text { cases }\end{array}$ & $\begin{array}{l}\text { On request } \\
\text { On request }\end{array}$ & $\begin{array}{l}\mathrm{N} \\
\mathrm{Y}\end{array}$ & $\begin{array}{l}\mathrm{Y} \\
\mathrm{Y}\end{array}$ & $\begin{array}{l}\mathrm{N} \\
\mathrm{N}\end{array}$ \\
\hline Hungary & $\begin{array}{l}1973-1992 \\
1993-\end{array}$ & $\begin{array}{l}\text { Legal for medical reasons or on request in first } 12 \text { weeks of pregnancy for certain categories of women, like those with } 3 \text { or more children } \\
\text { Legal in the first } 12 \text { weeks of pregnancy after counselling and a 3-day waiting period }\end{array}$ & $\begin{array}{l}\text { Medical/Social } \\
\text { On request }\end{array}$ & & & \\
\hline Latvia & 1955- & Legal on request in the first 12 weeks of pregnancy following consultation with doctor and notification of possible adverse consequences & On request & $\mathrm{Y}$ & Y & $\mathrm{N}$ \\
\hline Lithuania & 1955- & Legal on request in the first 12 weeks of pregnancy following consultation with doctor and notification of possible adverse consequences & On request & $\mathrm{Y}$ & $\mathrm{Y}$ & $\mathrm{N}$ \\
\hline Moldova & $1955-$ & Legal on request in the first 12 weeks of pregnancy following consultation with doctor and notification of possible adverse consequences & On request & $\mathrm{Y}$ & $\mathrm{Y}$ & $\mathrm{N}$ \\
\hline Poland & $\begin{array}{l}1956-1992 \\
1993-\end{array}$ & $\begin{array}{l}\text { Legal in the first } 12 \text { weeks of pregnancy for medical and social reasons } \\
\text { Legal only when the pregnancy threatens the mother's life or health or in cases of rape/incest or foetal defects }\end{array}$ & $\begin{array}{l}\text { Medical/Social } \\
\text { Life/Medical }\end{array}$ & $\begin{array}{l}\mathrm{Y} \\
\mathrm{NA}\end{array}$ & $\begin{array}{l}\mathrm{Y} \\
\mathrm{NA}\end{array}$ & $\begin{array}{l}\mathrm{Y} \\
\mathrm{NA}\end{array}$ \\
\hline Romania & $\begin{array}{l}1966-1989 \\
1990-\end{array}$ & $\begin{array}{l}\text { Legal in very limited circumstances (mother's life, rape, very large family, and the like) } \\
\text { Legal on request in the first } 12 \text { weeks of pregnancy }\end{array}$ & $\begin{array}{l}\text { Life/Medical } \\
\text { On request }\end{array}$ & $\begin{array}{l}\mathrm{NA} \\
\mathrm{N}\end{array}$ & $\begin{array}{l}\mathrm{NA} \\
\mathrm{Y}\end{array}$ & $\begin{array}{l}\text { NA } \\
\mathrm{N}\end{array}$ \\
\hline Russia & 1955- & $\begin{array}{l}\text { Legal on request in the first } 12 \text { weeks of pregnancy following consultation with doctor and notification of possible adverse consequences } \\
\end{array}$ & On request & $\mathrm{Y}$ & $\mathrm{Y}$ & $\mathrm{N}$ \\
\hline Slovak Republic & $\begin{array}{l}1957-1986 \\
1987-\end{array}$ & $\begin{array}{l}\text { Legal for maternal health or social reasons in the first } 12 \text { weeks of pregnancy } \\
\text { Legal in the first } 12 \text { weeks of pregnancy on request and physician approval }\end{array}$ & $\begin{array}{l}\text { Medical/Social } \\
\text { On request }\end{array}$ & $\begin{array}{l}\mathrm{Y} \\
\mathrm{N}\end{array}$ & $\begin{array}{l}\mathrm{Y} \\
\mathrm{Y}\end{array}$ & $\begin{array}{l}\mathrm{N} \\
\mathrm{Y}\end{array}$ \\
\hline
\end{tabular}

Source: Levine and Staiger (2004) 
Table A2 Change in real GDP per capita in Eastern Europe (1980-1997)

\begin{tabular}{|l|c|c|c|c|}
\hline Country & $\mathbf{1 9 8 0 - 8 4}$ (\% change) & $\mathbf{1 9 8 5 - 8 8 ~ ( \% ~ c h a n g e ) ~}$ & $\mathbf{1 9 8 9 - 9 2 ~ ( \% ~ c h a n g e ) ~}$ & $\mathbf{1 9 9 3}$-97 (\% change) \\
\hline Bulgaria & 8.6 & 22.3 & -19.8 & -10.7 \\
\hline Czech Republic & 5.8 & 4.6 & -20.3 & 23.4 \\
\hline Estonia & 10.4 & 5.4 & -31.5 & 30.8 \\
\hline Germany (GDR) & & 4.3 & -16.9 & 12.3 \\
\hline Hungary & 7.1 & 6.9 & -41.5 & 15.2 \\
\hline Latvia & 11.9 & 9.5 & -19.8 & 3.9 \\
\hline Lithuania ${ }^{1}$ & 5.1 & 14.1 & -42.9 & -36.1 \\
\hline Moldova & 17.1 & 8.3 & -16.5 & 27.0 \\
\hline Poland & 3.3 & 8.7 & -23.9 & 9.1 \\
\hline Romania & 15.7 & -4.6 & -21.8 & -17.8 \\
\hline Russia & 5.5 & 5.3 & -22.9 & 25.9 \\
\hline Slovak Republic ${ }^{2}$ & 4.2 & 6.9 & & \\
\hline
\end{tabular}

${ }^{1}$ missing data for $1980-84$ and $1997^{2}$ missing data for 1980

Source: World Bank and CIA. 
Table A3 Inflation rates in Eastern Europe (1980-1997)

\begin{tabular}{|c|c|c|c|c|c|}
\hline Country & less than $5 \%$ & between $5 \%-25 \%$ & between $25 \%-100 \%$ & greater than $100 \%$ & missing data \\
\hline Bulgaria & $1980-88$ & 1989 & 1992-95 & 1991, 1996-97 & 1980,1990 \\
\hline Czech Republic & 1981-89 & $1990,1992-97$ & 1991 & & 1980 \\
\hline Estonia & 1981-85, 1987-88 & 1986, 1989-90,1996-97 & 1993-95 & 1991-92 & 1980 \\
\hline Germany (GDR) & 1981-89, 1994-97 & 1992-93 & & & 1980, 1990-91 \\
\hline Hungary & 1981 & 1980, 1982-1989, 1992-94, 1996-97 & 1990-91, 1995 & & \\
\hline Latvia & 1981-85, 1987-88 & 1986, 1989-90, 1996-97 & 1994, 1995 & 1991-93 & 1980 \\
\hline Lithuania & 1981-85 & 1986, 1989-90, 1996-97 & 1987-88, 1994-95 & 1991-93 & 1980 \\
\hline Moldova & 1981-85, 1987-88 & 1986, 1989-90, 1996-97 & 1991, 1995 & 1992-94 & 1980 \\
\hline Poland & & 1980-81, 1984-86, 1996-97 & 1983, 1987-88, 1991-95 & 1982, 1989-90 & \\
\hline Romania & 1984-88 & 1981-83, 1989-90 & $1995-96$ & 1991-94, 1997 & 1980 \\
\hline Russia & 1980-84, 1986-87 & 1985, 1988-90, 1997 & 1996 & 1991-95 & \\
\hline Slovak Republic & 1981-89 & $1990,1992-97$ & 1991 & & 1980 \\
\hline
\end{tabular}

Source: World Bank and CIA. 
Table A4 Percentage of Females Aged 20-24 Enrolled in University Education in Eastern Europe (1980 and 1995)

\begin{tabular}{|l|c|c|c|}
\hline Country & $\mathbf{1 9 8 0}$ & $\mathbf{1 9 9 5}$ & \% change \\
\hline Bulgaria & 18.5 & 51.9 & 180.9 \\
\hline Czech Republic & 14.0 & 21.2 & 51.5 \\
\hline Estonia & 25.5 & 40.4 & - \\
\hline Germany (GDR) & 36.1 & - & 113.8 \\
\hline Hungary & 12.6 & 26.9 & 6.1 \\
\hline Latvia & 28.1 & 29.8 & -26.7 \\
\hline Lithuania $^{2}$ & 44.6 & 32.6 & - \\
\hline Moldova & & \\
\hline Poland & - & 29.6 & 45.9 \\
\hline Romania & 20.1 & 23.9 & 150.9 \\
\hline Russia $^{4}$ & 9.5 & - & - \\
\hline Slovak Republic & 51.5 & 21.1 & - \\
\hline
\end{tabular}

${ }^{1}$ Data only available for 1980-1988, ${ }^{2}$ 1980-1984 missing (1985 used), ${ }^{3}$ Data only available for $1994-1996,{ }^{4}$ Data only available for 1980-1986, ${ }^{5}$ Data only available for $1992-1996$

Source: UNESCO (various years) 
Table A5 Urbanization in Eastern Europe (1982 and 1997)

\begin{tabular}{|l|c|c|c|}
\hline Country & $\mathbf{1 9 8 2}$ & $\mathbf{1 9 9 7}$ & \% change \\
\hline Bulgaria & 63.9 & 67.7 & +5.9 \\
\hline Czech Republic & 73.7 & 74.7 & -2.1 \\
\hline Estonia & 70.8 & 69.3 & -0.3 \\
\hline Germany (GDR) & 76.5 & 76.3 & +11.3 \\
\hline Hungary & 57.3 & 63.8 & -1.1 \\
\hline Latvia & 69.9 & 69.1 & +7.9 \\
\hline Lithuania & 63.3 & 68.3 & -2.6 \\
\hline Moldova & & 41.7 & +4.4 \\
\hline Poland & 42.8 & 61.9 & +13.4 \\
\hline Romania & 59.3 & 55.0 & +1.8 \\
\hline Russia & 48.5 & 72.9 & +7.5 \\
\hline Slovak Republic & & & \\
\hline
\end{tabular}

${ }^{1}$ 1991-97 missing (1990 used), ${ }^{2}$ 1980-83 missing (1984 used), ${ }^{3} 1980-83$ missing (1984 used), ${ }^{4} 1980-82$ missing (1983 used)

Source: United Nations Demographic Yearbook (various years) 
Table A6 Female-to-male population ratios in Eastern Europe (1980 and 1996)

\begin{tabular}{|c|c|c|c|c|c|c|c|c|c|c|c|c|c|c|}
\hline & \multicolumn{2}{|c|}{$15-44$} & \multicolumn{2}{|c|}{$15-19$} & \multicolumn{2}{|c|}{$20-24$} & \multicolumn{2}{|c|}{$25-29$} & \multicolumn{2}{|c|}{$30-34$} & \multicolumn{2}{|c|}{$35-39$} & \multicolumn{2}{|c|}{$40-44$} \\
\hline & 1980 & 1996 & 1980 & 1996 & 1980 & 1996 & 1980 & 1996 & 1980 & 1996 & 1980 & 1996 & 1980 & 1996 \\
\hline Czech Republic & 0.97 & 0.96 & 0.95 & 0.95 & 0.96 & 0.95 & 0.97 & 0.95 & 0.97 & 0.96 & 0.99 & 0.97 & 1.00 & 0.99 \\
\hline Estonia & 0.98 & 0.99 & 0.90 & 0.96 & 0.92 & 0.97 & 0.96 & 0.91 & 1.02 & 0.99 & 1.04 & 1.04 & 1.08 & 1.08 \\
\hline Hungary & 0.98 & 0.97 & 0.94 & 0.95 & 0.96 & 0.95 & 0.97 & 0.96 & 0.98 & 0.97 & 1.00 & 1.00 & 1.09 & 1.09 \\
\hline Latvia & 1.00 & 0.99 & 0.93 & 0.97 & 0.94 & 0.96 & 0.99 & 0.93 & 1.02 & 0.99 & 1.05 & 1.04 & 1.09 & 1.09 \\
\hline Lithuania & 1.00 & 0.99 & 0.92 & 0.97 & 0.95 & 0.97 & 0.99 & 0.95 & 1.04 & 0.98 & 1.06 & 1.03 & 1.11 & 1.07 \\
\hline Moldova* & 1.06 & 1.03 & 0.98 & 0.97 & 1.07 & 0.99 & 1.06 & 1.02 & 1.08 & 1.07 & 1.11 & 1.06 & 1.14 & 1.08 \\
\hline Slovak Republic & 0.98 & 0.97 & 0.96 & 0.94 & 0.94 & 0.96 & 0.96 & 0.96 & 0.96 & 0.98 & 1.03 & 0.97 & 1.06 & 0.99 \\
\hline
\end{tabular}

* figures are 1994 for 1996.

Source: Council of Europe 
Table A7 Divorce Laws in Eastern Europe

\begin{tabular}{|l|l|}
\hline Country & Divorce legislation \\
\hline Bulgaria & From 1968-1985: Breakdown or other less restrictive; Since 1985: Fault or other restrictive \\
\hline Czech Republic & From 1950-1964: Fault or other restrictive; From 1964- 1998: Breakdown or other less restrictive \\
\hline Estonia & Until 1966: Fault or other restrictive; Since 1966: Breakdown or other less restrictive \\
\hline Germany (GDR) & From 1949-1990: Breakdown or other less restrictive; Since 1990, more restrictive \\
\hline Hungary & Until 1964: Fault or other restrictive; Since 1964: Breakdown or other less restrictive \\
\hline Latvia & Until 1966: Fault or other restrictive; Since 1966: Breakdown or other less restrictive \\
\hline Lithuania & Until 1966: Fault or other restrictive; Since 1966: Breakdown or other less restrictive \\
\hline Moldova & Until 1966: Fault or other restrictive; Since 1966: Breakdown or other less restrictive \\
\hline Poland & Until 1964: Fault or other restrictive; Since 1964: Breakdown or other less restrictive \\
\hline Romania & From 1966-1993: Fault or other restrictive; Since 1993: Breakdown or other less restrictive \\
\hline Russia & Until 1966: Fault or other restrictive; Since 1966: Breakdown or other less restrictive \\
\hline Slovak Republic & From 1950-1964: Fault or other restrictive; From 1964- 1998: Breakdown or other less restrictive \\
\hline
\end{tabular}

Sources: Martiny and Schwab (2003), Todorova (2003), Antokolskaia (2003), Weiss and Szeibert (2003), Maczynski and Sokolowski (2003), Harkonen and Dronkers (2006), the Max Planck Institute for Demographic Research, and direct correspondence with legal experts in Eastern Europe. 


\begin{tabular}{|l|c|c|c|c|c|c|c|c|}
\hline & $\mathbf{1 5 - 1 9}$ & $\mathbf{1 5 - 1 9}$ & $\mathbf{1 5 - 1 9}$ & $\mathbf{1 5 - 1 9}$ & $\mathbf{2 0 - 2 4}$ & $\mathbf{2 0 - 2 4}$ & $\mathbf{2 0 - 2 4}$ & $\mathbf{2 0 - 2 4}$ \\
\hline & $\mathbf{( 1 )}$ & $\mathbf{( 2 )}$ & $\mathbf{( 3 )}$ & $\mathbf{( 4 )}$ & $\mathbf{( 1 )}$ & $\mathbf{( 2 )}$ & $\mathbf{( 3 )}$ & $\mathbf{( 4 )}$ \\
\hline $\begin{array}{l}\text { Strict abortion law } \\
\text { effective for 1 yr }\end{array}$ & $\begin{array}{c}47.6 \\
(21.3)^{* *}\end{array}$ & $\begin{array}{c}14.3 \\
(15.7)\end{array}$ & $\begin{array}{c}14.6 \\
(14.9)\end{array}$ & $\begin{array}{c}30.3 \\
(21.6)\end{array}$ & $\begin{array}{c}-13.0 \\
(23.1)\end{array}$ & $\begin{array}{c}-26.0 \\
(17.5)\end{array}$ & $\begin{array}{c}-12.0 \\
(19.2)\end{array}$ & $\begin{array}{c}-42.7 \\
(16.9)^{* * *}\end{array}$ \\
\hline $\begin{array}{l}\text { Strict abortion law } \\
\text { effective for 2 yrs }\end{array}$ & -35.7 & -6.07 & -19.9 & -17.1 & -0.53 & -10.7 & -8.88 & 0.72 \\
$(23.7)$ & $(15.0)$ & $(16.0)$ & $(21.0)$ & $(27.4)$ & $(17.3)$ & $(18.9)$ & $(20.5)$ \\
\hline $\begin{array}{l}\text { On request abortion law } \\
\text { effective for 1 yr }\end{array}$ & -40.7 & 14.4 & 5.12 & -41.8 & 47.2 & 1.31 & 21.6 & 5.09 \\
$(19.7)^{*}$ & $(11.4)$ & $(11.6)$ & $(19.5)^{*}$ & $(16.1)^{* * *}$ & $(13.0)$ & $(13.7)$ & $(11.0)$ \\
\hline $\begin{array}{l}\text { On request abortion law } \\
\text { effective for 2 yrs }\end{array}$ & 0.80 & 1.26 & -7.19 & 4.02 & -2.32 & 1.31 & 4.41 & 5.95 \\
$(24.2)$ & $(12.8)$ & $(12.9)$ & $(20.6)$ & $(24.5)$ & $(16.4)$ & $(17.7)$ & $(15.2)$ \\
\hline $\begin{array}{l}\text { On request abortion law } \\
\text { effective for 3 yrs }\end{array}$ & -24.7 & 20.7 & -0.44 & -15.0 & 23.6 & 2.41 & 10.6 & 4.97 \\
$(18.4)$ & $(11.6)^{*}$ & $(11.4)$ & $(19.4)$ & $(19.1)$ & $(12.8)$ & $(13.8)$ & $(13.6)$ \\
\hline $\begin{array}{l}\text { Country-specific linear } \\
\text { trends }\end{array}$ & $\mathrm{N}$ & $\mathrm{Y}$ & $\mathrm{N}$ & $\mathrm{N}$ & $\mathrm{N}$ & $\mathrm{N}$ & $\mathrm{Y}$ & $\mathrm{N}$ \\
\hline $\begin{array}{l}\text { Country-specific } \\
\text { quadratic trends }\end{array}$ & $\mathrm{N}$ & $\mathrm{N}$ & $\mathrm{Y}$ & $\mathrm{N}$ & $\mathrm{N}$ & $\mathrm{Y}$ & $\mathrm{N}$ & $\mathrm{N}$ \\
\hline R & 0.88 & 0.96 & 0.96 & 0.90 & 0.90 & 0.94 & 0.93 & 0.94 \\
\hline F-statistic (strict) & 0.41 & 0.12 & 0.06 & 0.44 & 0.47 & $3.81^{* *}$ & 1.01 & $6.79^{* * *}$ \\
\hline F-statistic (on request) & $18.5^{* * *}$ & $6.64^{* * *}$ & 0.03 & $7.41^{* * *}$ & $50.8^{* * *}$ & 0.99 & $7.42^{* * *}$ & 2.42 \\
\hline Sample size & 208 & 208 & 208 & 208 & 208 & 208 & 208 & 172 \\
\hline
\end{tabular}

The dependent variables are first female marriage rate per 1000 women for each age group. All models include county and year fixed effects and dummy variables indicating whether GDP and inflation data are missing. They are also weighted by the size of the relevant population. Standard errors are reported in parentheses and are corrected for heteroscedasticity. The omitted abortion law category is 'legal for medical or social reasons'.

*** $\mathrm{p}<0.01 * * \mathrm{p}<0.05 * \mathrm{p}<0.10$ (two-tailed tests, under $\mathrm{H}_{0}: \beta=0$ ) 
Table A9 OLS estimates of the (dynamic) effect of abortion laws on first marriage rates of females in Eastern Europe

\begin{tabular}{|c|c|c|c|c|c|c|c|c|}
\hline & $25-29$ & $25-29$ & $25-29$ & $25-29$ & $30-34$ & $30-34$ & $30-34$ & $30-34$ \\
\hline & (1) & (2) & (3) & (4) & (1) & (2) & (3) & (4) \\
\hline $\begin{array}{l}\text { Strict abortion law } \\
\text { effective for } 1 \mathrm{yr}\end{array}$ & $\begin{array}{l}-4.95 \\
(5.84)\end{array}$ & $\begin{array}{l}-1.25 \\
(4.12)\end{array}$ & $\begin{array}{l}-2.35 \\
(4.76)\end{array}$ & $\begin{array}{c}-14.5 \\
(4.47)^{* * *}\end{array}$ & $\begin{array}{c}0.42 \\
(1.26)\end{array}$ & $\begin{array}{c}1.71 \\
(1.09)\end{array}$ & $\begin{array}{c}1.00 \\
(1.13)\end{array}$ & $\begin{array}{l}-1.93 \\
(1.24)\end{array}$ \\
\hline $\begin{array}{l}\text { Strict abortion law } \\
\text { effective for } 2 \text { yrs }\end{array}$ & $\begin{array}{c}2.61 \\
(6.14)\end{array}$ & $\begin{array}{l}-5.03 \\
(3.58)\end{array}$ & $\begin{array}{l}-2.84 \\
(4.48)\end{array}$ & $\begin{array}{c}2.05 \\
(4.56)\end{array}$ & $\begin{array}{c}0.86 \\
(1.44)\end{array}$ & $\begin{array}{c}-0.93 \\
(1.04)\end{array}$ & $\begin{array}{l}-0.58 \\
(1.19)\end{array}$ & $\begin{array}{l}-0.28 \\
(1.47)\end{array}$ \\
\hline $\begin{array}{l}\text { On request abortion } \\
\text { law effective for } 1 \mathrm{yr}\end{array}$ & $\begin{array}{c}17.7 \\
(5.36)^{* * *}\end{array}$ & $\begin{array}{c}5.54 \\
(3.58)\end{array}$ & $\begin{array}{c}10.3 \\
(4.18)^{* * *}\end{array}$ & $\begin{array}{c}9.80 \\
(4.09)^{* * *}\end{array}$ & $\begin{array}{c}3.75 \\
(1.57)^{* * *}\end{array}$ & $\begin{array}{c}1.10 \\
(1.38)\end{array}$ & $\begin{array}{c}2.15 \\
(1.55)\end{array}$ & $\begin{array}{c}1.81 \\
(1.34)\end{array}$ \\
\hline $\begin{array}{l}\text { On request abortion } \\
\text { law effective for } 2 \text { yrs }\end{array}$ & $\begin{array}{l}-0.83 \\
(8.26)\end{array}$ & $\begin{array}{l}-0.80 \\
(4.49)\end{array}$ & $\begin{array}{c}0.26 \\
(5.26)\end{array}$ & $\begin{array}{l}-0.42 \\
(5.71)\end{array}$ & $\begin{array}{l}-0.66 \\
(2.04)\end{array}$ & $\begin{array}{l}-0.99 \\
(1.59)\end{array}$ & $\begin{array}{l}-0.75 \\
(1.75)\end{array}$ & $\begin{array}{l}-0.80 \\
(1.71)\end{array}$ \\
\hline $\begin{array}{l}\text { On request abortion } \\
\text { law effective for } 3 \text { yrs }\end{array}$ & $\begin{array}{c}15.8 \\
(6.66)^{* * *}\end{array}$ & $\begin{array}{c}5.44 \\
(3.39)\end{array}$ & $\begin{array}{c}10.8 \\
(4.09)^{* * *}\end{array}$ & $\begin{array}{c}4.59 \\
(5.18)\end{array}$ & $\begin{array}{c}6.00 \\
(1.44)^{* * * *}\end{array}$ & $\begin{array}{c}3.48 \\
(0.97)^{*} \\
* *\end{array}$ & $\begin{array}{c}4.86 \\
(1.12)^{*} \\
* *\end{array}$ & $\begin{array}{c}4.86 \\
(1.28)^{* * *}\end{array}$ \\
\hline $\begin{array}{l}\text { Country-specific linear } \\
\text { trends }\end{array}$ & $\mathrm{N}$ & $\mathrm{Y}$ & $\mathrm{N}$ & $\mathrm{N}$ & $\mathrm{N}$ & $\mathrm{N}$ & $\mathrm{N}$ & $\mathrm{N}$ \\
\hline $\begin{array}{l}\text { Country-specific } \\
\text { quadratic trends }\end{array}$ & $\mathrm{N}$ & $\mathrm{N}$ & $\mathrm{Y}$ & $\mathrm{N}$ & $\mathrm{N}$ & $\mathrm{Y}$ & $\mathrm{Y}$ & $\mathrm{N}$ \\
\hline $\mathrm{R}^{2}$ & 0.80 & 0.89 & 0.87 & 0.85 & 0.90 & 0.92 & 0.92 & 0.93 \\
\hline F-statistic (strict) & 0.36 & 1.49 & 1.18 & $7.31^{* * *}$ & 1.18 & 0.37 & 0.14 & 0.50 \\
\hline F-statistic (on request) & $93.1 * * *$ & $\begin{array}{c}6.54^{* *} \\
*\end{array}$ & $27.2 * * *$ & $10.6^{* * *}$ & $27.2 * * *$ & $\begin{array}{l}12.7 * * \\
*\end{array}$ & $35.9 * *$ & $20.7 * * *$ \\
\hline Sample size & 208 & 208 & 208 & 172 & 208 & 208 & 208 & 172 \\
\hline
\end{tabular}

The dependent variables are first female marriage rate per 1000 women for each age group. All models include county and year fixed effects and dummy variables indicating whether GDP and inflation data are missing. They are also weighted by the size of the relevant population. Standard errors are reported in parentheses and are corrected for heteroscedasticity. The omitted abortion law category is 'legal for medical or social reasons'.

*** $\mathrm{p}<0.01 * * \mathrm{p}<0.05 * \mathrm{p}<0.10$ (two-tailed tests, under $\mathrm{H}_{0}: \beta=0$ ) 
Table A10 OLS estimates of the (dynamic) effect of abortion laws on first marriage rates of females in Eastern Europe

\begin{tabular}{|c|c|c|c|c|c|c|c|c|}
\hline & 35-39 & 35-39 & 35-39 & $35-39$ & $40-44$ & $40-44$ & $40-44$ & $40-44$ \\
\hline & (1) & (2) & (3) & (4) & (1) & (2) & (3) & (4) \\
\hline $\begin{array}{l}\text { Strict abortion law } \\
\text { effective for } 1 \mathrm{yr}\end{array}$ & $\begin{array}{l}-0.11 \\
(0.50)\end{array}$ & $\begin{array}{c}0.48 \\
(0.50)\end{array}$ & $\begin{array}{c}0.18 \\
(0.57)\end{array}$ & $\begin{array}{c}-1.16 \\
(0.50)^{* *}\end{array}$ & $\begin{array}{l}0.006 \\
(0.31)\end{array}$ & $\begin{array}{l}-0.06 \\
(0.34)\end{array}$ & $\begin{array}{l}-0.11 \\
(0.31)\end{array}$ & $\begin{array}{l}-0.48 \\
(0.31)\end{array}$ \\
\hline $\begin{array}{l}\text { Strict abortion law } \\
\text { effective for } 2 \text { yrs }\end{array}$ & $\begin{array}{c}1.48 \\
(0.74)^{* *}\end{array}$ & $\begin{array}{c}0.49 \\
(0.51)\end{array}$ & $\begin{array}{c}0.72 \\
(0.57)\end{array}$ & $\begin{array}{c}0.76 \\
(0.50)\end{array}$ & $\begin{array}{c}0.88 \\
(0.39)\end{array}$ & $\begin{array}{c}0.01 \\
(0.37)\end{array}$ & $\begin{array}{c}0.27 \\
(0.35)\end{array}$ & $\begin{array}{c}0.09 \\
(0.30)\end{array}$ \\
\hline $\begin{array}{l}\text { On request abortion } \\
\text { law effective for } 1 \mathrm{yr}\end{array}$ & $\begin{array}{c}1.29 \\
(0.53)^{* * *}\end{array}$ & $\begin{array}{l}-0.01 \\
(0.51)\end{array}$ & $\begin{array}{c}0.38 \\
(0.57)\end{array}$ & $\begin{array}{c}0.47 \\
(0.42)\end{array}$ & $\begin{array}{c}0.95 \\
(0.32)^{* * *}\end{array}$ & $\begin{array}{l}6 \mathrm{E}-04 \\
(0.31)\end{array}$ & $\begin{array}{c}0.21 \\
(0.31)\end{array}$ & $\begin{array}{c}0.58 \\
(0.28)\end{array}$ \\
\hline $\begin{array}{l}\text { On request abortion } \\
\text { law effective for } 2 \text { yrs }\end{array}$ & $\begin{array}{c}0.13 \\
(0.73)\end{array}$ & $\begin{array}{l}-0.07 \\
(0.59)\end{array}$ & $\begin{array}{c}0.06 \\
(0.66)\end{array}$ & $\begin{array}{l}-1.66 \\
(0.59)\end{array}$ & $\begin{array}{c}0.02 \\
(0.50)\end{array}$ & $\begin{array}{l}-0.11 \\
(0.40)\end{array}$ & $\begin{array}{l}0.009 \\
(0.43)\end{array}$ & $\begin{array}{l}-0.19 \\
(0.39)\end{array}$ \\
\hline $\begin{array}{l}\text { On request abortion } \\
\text { law effective for } 3 \text { yrs }\end{array}$ & $\begin{array}{c}2.25 \\
(0.59)^{* * *}\end{array}$ & $\begin{array}{c}0.90 \\
(0.43)^{* * *}\end{array}$ & $\begin{array}{c}1.56 \\
(0.49)^{* *}\end{array}$ & $\begin{array}{c}1.99 \\
(0.55)^{* * *}\end{array}$ & $\begin{array}{c}1.57 \\
(0.45)^{* * *}\end{array}$ & $\begin{array}{c}0.69 \\
(0.32)^{* *}\end{array}$ & $\begin{array}{c}1.06 \\
(0.37)^{* * *}\end{array}$ & $\begin{array}{c}1.29 \\
(0.33)^{* * *}\end{array}$ \\
\hline $\begin{array}{l}\text { Country-specific linear } \\
\text { trends }\end{array}$ & $\mathrm{N}$ & $\mathrm{Y}$ & $\mathrm{N}$ & $\mathrm{N}$ & $\mathrm{N}$ & $\mathrm{Y}$ & $\mathrm{N}$ & $\mathrm{N}$ \\
\hline $\begin{array}{l}\text { Country-specific } \\
\text { quadratic trends }\end{array}$ & $\mathrm{N}$ & $\mathrm{N}$ & $\bar{Y}$ & $\mathrm{~N}$ & $\mathrm{~N}$ & $\mathrm{~N}$ & $\mathrm{Y}$ & $\mathrm{N}$ \\
\hline $\mathrm{R}^{2}$ & 0.93 & 0.92 & 0.93 & 0.93 & 0.93 & 0.93 & 0.93 & 0.92 \\
\hline F-statistic (strict) & $9.97 * * *$ & $3.52 *$ & $3.31 *$ & 0.50 & $8.49 * * *$ & 0.02 & 0.21 & 1.36 \\
\hline F-statistic (on request) & $75.0 * * *$ & $40.4^{* * *}$ & $16.3^{* * *}$ & $20.7 * * *$ & $72.7 * * *$ & $4.27 * *$ & $18.0 * * *$ & $34.1^{* * *}$ \\
\hline Sample size & 208 & 208 & 208 & 172 & 208 & 208 & 208 & 172 \\
\hline
\end{tabular}

The dependent variables are first female marriage rate per 1000 women for each age group. All models include county and year fixed effects and dummy variables indicating whether GDP and inflation data are missing. They are also weighted by the size of the relevant population. Standard errors are reported in parentheses and are corrected for heteroscedasticity. The omitted abortion law category is 'legal for medical or social reasons'.

*** $\mathrm{p}<0.01 * * \mathrm{p}<0.05 * \mathrm{p}<0.10$ (two-tailed tests, under $\mathrm{H}_{0}: \beta=0$ ) 